First Version

\title{
Kinetics of Chlorination and Oxychlorination of Chromium (III) Oxide
}

\author{
I. GABALLAH, S. IVANAJ and N. KANARI \\ Mineral Processing and Environmental Engineering team, LEM ${ }^{\mathrm{a}}$ \\ Associated to $\mathrm{CNRS}^{\mathrm{b}}$ URA 235, ENSG' ${ }^{\mathrm{c}}$, INPL ${ }^{\mathrm{d}}$, BP 40, 54501 Vandœuvre, France.
}

Thermogravimetric analysis (TGA) is used to study the kinetics of chlorination of $\mathrm{Cr}_{2} \mathrm{O}_{3}$ with $\mathrm{Cl}_{2}+\mathrm{N}_{2}$ and $\mathrm{Cl}_{2}+\mathrm{O}_{2}$ gas mixtures in the temperature range of $550{ }^{\circ} \mathrm{C}$ to $1000{ }^{\circ} \mathrm{C}$. The reactivity of $\mathrm{Cr}_{2} \mathrm{O}_{3}$ towards chlorine-oxygen gas mixture is higher than that of chlorine-nitrogen one.

Chlorination of $\mathrm{Cr}_{2} \mathrm{O}_{3}$ proceeds with an apparent activation energy of about $86 \mathrm{~kJ} / \mathrm{mol}$ between $550{ }^{\circ} \mathrm{C}$ and $1000{ }^{\circ} \mathrm{C}$. The apparent reaction order with respect to chlorine is about 1.23 at $800{ }^{\circ} \mathrm{C}$. At temperatures lower than $650{ }^{\circ} \mathrm{C}$, the shrinking sphere model is the most appropriate for describing the reaction kinetics ${ }^{[19]}$.

Oxychlorination of $\mathrm{Cr}_{2} \mathrm{O}_{3}$ is characterized by an apparent activation energy of about 87 and 46 $\mathrm{kJ} / \mathrm{mol}$ for temperatures lower than $650{ }^{\circ} \mathrm{C}$ and higher than $700{ }^{\circ} \mathrm{C}$, respectively. At $800{ }^{\circ} \mathrm{C}$ and using a $\mathrm{Cl}_{2}+\mathrm{O}_{2}$ gas mixture, the maximum reaction rate is obtained by using a gas mixture having a $\mathrm{Cl}_{2} / \mathrm{O}_{2}$ molar ratio equal to 4 confirming the formation of chromium oxychloride. At this temperature, the reaction order with respect to chlorine, oxygen and $\mathrm{Cl}_{2}+\mathrm{O}_{2}$ is about $1.08,0.23$ and 1.29 , respectively. All the experimental data match with the general kinetic equation : $k t=1-(1-X)^{1 / F(p)}=k t^{[19]}$. Only, the value of the particle shape factor, ' $F(p)$ ', is different.

\footnotetext{
a. Laboratoire Environnement et Minéralurgie, rue du Doyen M. Roubault, BP 40, 54501 Vandœuvre Cedex, France.

b. Centre National de la Recherche Scientifique, 3 rue Michel-Ange, 75794 Paris Cedex, France.

c. Ecole National Supérieure de Géologie, rue du Doyen M. Roubault, BP 40, 54501 Vandœuvre Cedex, France.

d. Institut National Polytechnique de Lorraine, 2 rue de la Forêt de Haye, 54501 Vandœuvre Cedex, France.
} 


\section{INTRODUCTION AND LITERATURE REVIEW}

Reactivity of chlorine towards metals and metal compounds is interesting for the recovery of a valuable element from their ores and/or from industrial wastes. The chlorides and oxychlorides of transition metals have, generally, a lower boiling points than their oxides. This may allow selective separation of one or several elements, from the gas phase, by controlled cooling of reaction products. Recently, chlorination was used for the recovery of Ta and $\mathrm{Nb}$ from theirs ores ${ }^{[1]}$ and tin slag ${ }^{[2]}$ as well as for the extraction of Mo and V from spent hydrorefining catalysts [3,4]. Chlorination is also investigated for the beneficiation of chromite concentrates and/or selective separation of chromium compounds $[5,6]$.

This paper is devoted to the study of the chlorination and the oxychlorination kinetics of chromium (III) oxide using $\mathrm{Cl}_{2}+\mathrm{N}_{2}$ and $\mathrm{Cl}_{2}+\mathrm{O}_{2}$ gas mixtures. This investigation is a part of a larger program concerning the chlorination of refractory metals such as $\mathrm{MoO}_{3}{ }^{[7]}, \mathrm{V}_{2} \mathrm{O}_{5}{ }^{[8]}, \mathrm{Nb}_{2} \mathrm{O}_{5}$ and $\mathrm{Ta}_{2} \mathrm{O}_{5}{ }^{[9]}$. Moreover, the generated data could be used for the beneficiation of chromite ores or concentrates and for the recovery of chromium compounds from industrial wastes.

Chlorination of $\mathrm{Mo}, \mathrm{V}, \mathrm{Nb}$ and $\mathrm{Ta}$ oxides, without a reducing agent, generates oxychlorides of these elements. The most common oxychlorides are those described by Eqs 1 to 4 . These reactions indicate that a half mole of oxygen is evolved because it substituted by a chlorine mole without changing the element valency. The most probable oxychloride of chromium is $\mathrm{CrO}_{2} \mathrm{Cl}_{2(\mathrm{~g})}{ }^{[10]}$. For this reason, the formation of $\mathrm{CrO}_{2} \mathrm{Cl}_{2(\mathrm{~g})}$ through the chlorination of $\mathrm{Cr}_{2} \mathrm{O}_{3}$ required extra oxygen as shown by $\mathrm{Eq} 5$.

The literature is relatively poor concerning the $\mathrm{Cr}-\mathrm{O}-\mathrm{Cl}$ system. The reaction products of chromium (III) oxide with chlorine could be $\mathrm{CrCl}_{2}, \mathrm{CrCl}_{3}, \mathrm{CrCl}_{4}$ and $\mathrm{CrO}_{2} \mathrm{Cl}_{2}$ depending on the temperature and $\mathrm{Cl}_{2}$ and $\mathrm{O}_{2}$ partial pressures of the system. Morozov and Fefelova ${ }^{[11]}$ studied the equilibrium of chlorination of $\mathrm{Cr}_{2} \mathrm{O}_{3}$ with $\mathrm{Cl}_{2}$ between $700{ }^{\circ} \mathrm{C}$ and $1000{ }^{\circ} \mathrm{C}$. They mentioned that the chlorination of chromium (III) oxide by chlorine at high temperature could lead to the formation of $\mathrm{CrCl}_{2}, \mathrm{CrCl}_{3}$ and $\mathrm{CrCl}_{4}$. These authors suggested that the formation of chromium oxychlorides, in the investigated temperature range, is almost improbable because of their instability at temperatures higher than $450{ }^{\circ} \mathrm{C}$. Sano and Belton[12] have a thermodynamic approach for the formation of $\mathrm{CrO}_{2} \mathrm{Cl}_{2}(\mathrm{~g})$ using the transpiration method. Theirs experiments consist on the measurement of the volatilization of chromic oxide in a $\mathrm{Cl}_{2}+\mathrm{O}_{2}+\mathrm{Ar}$ atmosphere. According to these authors, the $\mathrm{CrO}_{2} \mathrm{Cl}_{2 \text { (g) }}$ is the chromium predominant product of $\mathrm{Cr}_{2} \mathrm{O}_{3}$ reaction with $\mathrm{Cl}_{2}+\mathrm{O}_{2}$ between $627^{\circ} \mathrm{C}$ to $977^{\circ} \mathrm{C}$ and the reaction is that described by Eq 5. Reinhold and Hauffe ${ }^{[13]}$ studied the chlorination kinetics of chromium metal and $\mathrm{Cr}_{2} \mathrm{O}_{3}$ pellets by thermogravimetric analysis (TGA). They concluded that the rate constant of $\mathrm{Cr}_{2} \mathrm{O}_{3}$ reaction with $\mathrm{Cl}_{2}+\mathrm{O}_{2}$ increases linearly with $\mathrm{Cl}_{2}$ pressure and with fourth root of the $\mathrm{O}_{2}$ pressure indicating that $\mathrm{CrO}_{2} \mathrm{Cl}_{2(\mathrm{~g})}$ could be the only reaction product. The investigation of Plies ${ }^{[14]}$ by mass spectrometric reveals the presence $\mathrm{CrOCl}_{2(\mathrm{~g})}$ in the gas phase of the system $\mathrm{CrOCl}-\mathrm{Cl}_{2}$ and $\mathrm{Cr}_{2} \mathrm{O}_{3}-\mathrm{Cl}_{2}$ between $627{ }^{\circ} \mathrm{C}$ and $1077{ }^{\circ} \mathrm{C}$. 


$$
\begin{array}{rlllllll}
\mathrm{MoO}_{3(\mathrm{~s})}+\mathrm{Cl}_{2(\mathrm{~g})} & & \rightarrow & & \mathrm{MoO}_{2} \mathrm{Cl}_{2(\mathrm{~g})}+1 / 2 & \mathrm{O}_{2(\mathrm{~g})} \\
1 / 3 \mathrm{~V}_{2} \mathrm{O}_{5(\mathrm{~s})}+\mathrm{Cl}_{2(\mathrm{~g})} & & \rightarrow & 2 / 3 & \mathrm{VOCl}_{3(\mathrm{~g})}+1 / 2 & \mathrm{O}_{2(\mathrm{~g})} \\
\mathrm{Nb}_{2} \mathrm{O}_{5(\mathrm{~s})}+\mathrm{Cl}_{2(\mathrm{~g})} & & \rightarrow & 2 & \mathrm{NbO}_{2} \mathrm{Cl}_{(\mathrm{g})}+1 / 2 & \mathrm{O}_{2(\mathrm{~g})} \\
& \mathrm{Ta}_{2} \mathrm{O}_{5(\mathrm{~s})}+\mathrm{Cl}_{2(\mathrm{~g})} & & & \rightarrow & 2 & \mathrm{TaO}_{2} \mathrm{Cl}_{(\mathrm{g})}+1 / 2 & \mathrm{O}_{2(\mathrm{~g})} \\
1 / 2 & \mathrm{Cr}_{2} \mathrm{O}_{3(\mathrm{~s})}+\mathrm{Cl}_{2(\mathrm{~g})}+1 / 4 & \mathrm{O}_{2(\mathrm{~g})} & \rightarrow & & \mathrm{CrO}_{2} \mathrm{Cl}_{2(\mathrm{~g})} & &
\end{array}
$$

The formation of $\mathrm{CrO}_{2} \mathrm{Cl}_{2}$ (g), during the oxychlorination of $\mathrm{Cr}_{2} \mathrm{O}_{3}$-forming alloys with $\mathrm{Cl}_{2}+\mathrm{O}_{2}+\mathrm{Ar}$, is also confirmed by Jacobson et al.[15] using mass spectrometric and TG techniques. In another paper, McNallan et al.[16] used the same techniques in attempt to test the corrosion of Ni-Cr alloys in flowing $\mathrm{Cl}_{2}+\mathrm{O}_{2}+\mathrm{Ar}$ gas mixtures. They mentioned that the principal volatile corrosion products are $\mathrm{NiCl}_{2}(\mathrm{~g})$ and $\mathrm{CrO}_{2} \mathrm{Cl}_{2}(\mathrm{~g})$.

\section{THERMODYNAMIC STUDY}

Equations 5 and 7 to 10 were considered to describe the possible chemical reactions of $\mathrm{Cr}_{2} \mathrm{O}_{3}$ with $\mathrm{Cl}_{2}+\mathrm{O}_{2}$ and $\mathrm{Cl}_{2}$ gas mixtures up to $1000{ }^{\circ} \mathrm{C}$. The formation of $\mathrm{CrCl}_{2}$ is neglected due to high oxidation ability of chlorine. The chromium oxychloride is presumed as the only product of reaction of $\mathrm{Cr}_{2} \mathrm{O}_{3}$ with $\mathrm{Cl}_{2}+\mathrm{O}_{2}$ (Eq 5). The evolution of the standard free energy changes $\left(\Delta \mathrm{G}^{\circ}\right)$ of these reactions, as a function of temperature, is shown in Figure 1. The thermodynamic data, used in this study, are those of Barin [17]. This figure shows that the standard free energy changes of all the reactions are positive. However, an important criterion for determining the thermodynamic possibility of a chemical reaction is the evaluation of its free energy change $(\Delta \mathrm{G})$ given by :

$$
\Delta \mathrm{G}=\Delta \mathrm{G}^{\circ}+\mathrm{RTLnK}
$$

Although the reaction described by equation 5 at $800{ }^{\circ} \mathrm{C}$ is characterized by $\Delta \mathrm{G}^{\circ}$ of about $20 \mathrm{~kJ} / \mathrm{mol}$, the value of equilibrium constant for $\Delta \mathrm{G}=0$ is about 0.106 . This value indicates that the formation of $\mathrm{CrO}_{2} \mathrm{Cl}_{2(\mathrm{~g})}$ is possible at this temperature specially that the partial pressure of this compound in the gas phase is very low. This enhances the oxychlorination rate of $\mathrm{Cr}_{2} \mathrm{O}_{3}$.

$$
\begin{array}{rlllll}
1 / 3 \mathrm{Cr}_{2} \mathrm{O}_{3}(\mathrm{~s}) & +\mathrm{Cl}_{2}(\mathrm{~g}) & \rightarrow & 2 / 3 \mathrm{CrCl}_{3}(\mathrm{~s})+1 / 2 \mathrm{O}_{2}(\mathrm{~g}) \\
1 / 4 \mathrm{Cr}_{2} \mathrm{O}_{3}(\mathrm{~s}) & +\mathrm{Cl}_{2}(\mathrm{~g}) & \rightarrow & 1 / 2 \mathrm{CrCl}_{4}(\mathrm{~g})+3 / 8 \mathrm{O}_{2}(\mathrm{~g}) \\
4 / 9 \mathrm{Cr}_{2} \mathrm{O}_{3}(\mathrm{~s}) & +\mathrm{Cl}_{2}(\mathrm{~g}) & \rightarrow & 2 / 9 & \mathrm{CrCl}_{3}(\mathrm{~s})+2 / 3 \mathrm{CrO}_{2} \mathrm{Cl}_{2}(\mathrm{~g}) \\
2 / 5 \mathrm{Cr}_{2} \mathrm{O}_{3}(\mathrm{~s}) & +\mathrm{Cl}_{2}(\mathrm{~g}) & \rightarrow & 1 / 5 \mathrm{CrCl}_{4}(\mathrm{~g})+3 / 5 \mathrm{CrO}_{2} \mathrm{Cl}_{2}(\mathrm{~g})
\end{array}
$$




\section{MATERIALS AND EXPERIMENTAL PROCEDURE}

The sample used in this study is a $\mathrm{Cr}_{2} \mathrm{O}_{3}$ powder supplied by LABORATOIRES STANDA having a purity higher than $99 \%$. The sample's spectra of X-rays diffraction (XRD) and that obtained by the electron probe microanalysis of the scanning electron microscope (EPMA-SEM) indicate the presence of only $\mathrm{Cr}_{2} \mathrm{O}_{3}$ phase. The specific surface area of the sample was about $3.8 \mathrm{~m}^{2} / \mathrm{g}$.

The chlorination kinetics of $\mathrm{Cr}_{2} \mathrm{O}_{3}$ was determined by thermogravimetric analysis technique described previously.[8] The experimental tests were carried out in non and isothermal conditions. A sample of about $40 \mathrm{mg}$, placed in a large boat, is used for each test. For TG tests in non isothermal conditions, the sample was directly heated in the chlorinating gas atmosphere. The furnace heating rate was kept at about $7{ }^{\circ} \mathrm{C} /$ minute. For isothermal runs, the sample was heated in nitrogen atmosphere to a given temperature before the introduction of the chlorinating gas mixture. The exhaust gases were neutralized by $\mathrm{NaOH}$ before their release to the atmosphere.

\section{RESULTS}

\section{A. Non Isothermal Treatment of $\mathrm{Cr}_{2} \mathrm{O}_{3}$ and $\mathrm{CrCl}_{3}$ in $\mathrm{Cl}_{2}+\mathrm{N}_{2}$ and $\mathrm{Cl}_{2}+\mathrm{O}_{2}$ Gas Mixtures}

Non isothermal TG measurements were performed up to $1000{ }^{\circ} \mathrm{C}$ to compare the reactivity of $\mathrm{Cr}_{2} \mathrm{O}_{3}$ towards $\mathrm{Cl}_{2}+\mathrm{N}_{2}$ and $\mathrm{Cl}_{2}+\mathrm{O}_{2}$ atmospheres. Figure 2 shows the evolution of the percent weight loss of chromium (III) oxide versus temperature during its chlorination and oxychlorination. This figure also includes the volatilization and/or reaction curves of $\mathrm{CrCl}_{3}$ using the same chlorinating atmosphere.

The data analysis indicates that $\mathrm{Cr}_{2} \mathrm{O}_{3}$ starts to react with the two gas mixtures at temperature higher than $550{ }^{\circ} \mathrm{C}$. However, the chlorination rate augments with increasing the oxygen partial pressure in the gas mixture. At $1000{ }^{\circ} \mathrm{C}$, the reaction extent of $\mathrm{Cr}_{2} \mathrm{O}_{3}$ with $\mathrm{Cl}_{2}+\mathrm{O}_{2}$ and $\mathrm{Cl}_{2}+\mathrm{N}_{2}$ was about 100 and 70 pct, respectively. The rate of volatilization and/or reaction of $\mathrm{CrCl}_{3}$ with the chlorinating gas mixtures depends on the oxygen partial pressure. Chromium trichloride starts to volatilize and/or to react with the reactive gases at about $475{ }^{\circ} \mathrm{C}$. The curve of pct weight loss of $\mathrm{CrCl}_{3}$ in $\mathrm{Cl}_{2}+\mathrm{O}_{2}$ undergoes an anomaly at about $630{ }^{\circ} \mathrm{C}$. The SEM and XRD analysis of residue obtained at this temperature indicate the presence of $\mathrm{Cr}_{2} \mathrm{O}_{3}$. This is probably due to the oxidation of $\mathrm{CrCl}_{3}$ according to equation 7 and in spite of the important chlorine partial pressure. 
It is important to underline that the reaction and/or volatilization rate of $\mathrm{CrCl}_{3}$ in $\mathrm{Cl}_{2}+\mathrm{N}_{2}$ is largely higher than the chlorination rate of $\mathrm{Cr}_{2} \mathrm{O}_{3}$ with this gas mixture. Thus, during $\mathrm{Cr}_{2} \mathrm{O}_{3}$ chlorination, the reaction rate can be evaluated by the weight loss of sample in the chlorinating atmosphere. On the other hand, the product of $\mathrm{Cr}_{2} \mathrm{O}_{3}$ oxychlorination $\left(\mathrm{CrO}_{2} \mathrm{Cl}_{2}(\mathrm{~g})\right)$ is very volatile in the temperature range explored as its boiling point is about $117^{\circ} \mathrm{C}[10,18]$.

\section{B. Kinetics of Chlorination of $\mathrm{Cr}_{2} \mathrm{O}_{3}$ by $\mathrm{Cl}_{2}+\mathrm{N}_{2}$}

1. Effect of gas flow rate

The effect of $\mathrm{Cl}_{2}+\mathrm{N}_{2}$ flow rate on the reaction rate is performed to determine the conditions where the external mass transfer phenomena could be minimized. A series of isothermal tests is carried out at $950{ }^{\circ} \mathrm{C}$ using a total gas flow rate that varies from 8 to $72 \mathrm{~L} / \mathrm{h}$ while keeping the $\mathrm{Cl}_{2} / \mathrm{N}_{2}$ molar ratio equal to 1 . Figure 3 illustrates the evolution of reaction rate as a function of gas velocity ' $\mathrm{V}_{\mathrm{g}}$ ' for a reaction extent $\mathrm{X}$ (weight ratio of reacted fraction to the initial sample) of 0.05 to 0.4 . It is clear that the reaction rate is independent for a gas velocity higher than $33 \mathrm{~cm} / \mathrm{min}$. A gas flow rate of $60 \mathrm{~L} / \mathrm{h}\left(\mathrm{V}_{\mathrm{g}} \approx 50 \mathrm{~cm} / \mathrm{min}\right)$ is used during the study of the chlorination kinetics of $\mathrm{Cr}_{2} \mathrm{O}_{3}$ with $\mathrm{Cl}_{2}+\mathrm{N}_{2}$.

\section{Effect of temperature}

The effect of temperature on the chlorination of $\mathrm{Cr}_{2} \mathrm{O}_{3}$ with $\mathrm{Cl}_{2}+\mathrm{N}_{2}\left(\mathrm{Cl}_{2} / \mathrm{N}_{2}=1\right)$ is studied between $550{ }^{\circ} \mathrm{C}$ and $1000{ }^{\circ} \mathrm{C}$. Figure 4 illustrates the evolution of pet weight loss of the sample versus time. The reaction rate augments steadily with the temperature increase. The temperature coefficient of the reaction rate is shown in Figure 5. Between $550{ }^{\circ} \mathrm{C}$ and $1000{ }^{\circ} \mathrm{C}$, the apparent activation energy ' $\mathrm{E}_{\mathrm{a}}$ ' of the chlorination of chromium oxide is $86 \pm 2 \mathrm{~kJ} / \mathrm{mol}$.

Different kinetics' equations are tried to correlate the experimental data with these asymptotic equations. The following equations (Eqs 11 to 14) could be used to describe the evolution of reaction extent as a function of time for this gas-solid reaction. They are deduced from those described by Szekely et al. [19]

$$
\begin{aligned}
& 1-(1-\mathrm{X})^{1 / \mathrm{Fp}}=\mathrm{kt} \\
& \mathrm{X}=\mathrm{kt} \quad\left(\text { for } \mathrm{F}_{\mathrm{p}}=1\right) \\
& 1-(1-\mathrm{X})^{1 / 2}=\mathrm{kt} \quad\left(\text { for } \mathrm{F}_{\mathrm{p}}=2\right) \\
& 1-(1-\mathrm{X})^{1 / 3}=\mathrm{kt} \quad\left(\text { for } \mathrm{F}_{\mathrm{p}}=3\right)
\end{aligned}
$$


where $\mathrm{X}=$ extent of reaction,

$\mathrm{F}_{\mathrm{p}}=$ particle shape factor ( 1 for infinite slabs, 2 for long cylinders, and 3 for spheres),

$\mathrm{k}=$ constant and $\mathrm{t}=$ chlorination time.

Equation 10 describes a reaction controlled by the chemical reaction in shrinking nonporous particles (with or without a solid porous product) and porous particles with unchanged overall sizes. It also applies for pore diffusion control in the case of complete gasification of porous solids.

The best mathematical fitting of the experimental data of Figure 4 (a) is obtained using Eq $14(0.0 \leq$ $\mathrm{X} \leq 0.8$ ) as illustrated by Figure 6 (a). The average correlation coefficient is about 0.998 . Between $800{ }^{\circ} \mathrm{C}$ and $1000{ }^{\circ} \mathrm{C}$, the best fitting of experimental data is obtained using Eq 12 with a correlation coefficient higher than 0.999 as shown in Figure 6 (b). The evolution of the particle shape factor for experimental data is shown in Figure 6 (c).

At temperatures lower than $700{ }^{\circ} \mathrm{C}$, the value of $\mathrm{F}_{\mathrm{p}}$ is about 3 describing the classical shrinking sphere model where the reaction product is a gas and the grain particles of chromium oxide decrease as the reaction extent increases. At temperatures higher than $800{ }^{\circ} \mathrm{C}$, the shape factor is about 1 that may indicate that the chlorination rate of $\mathrm{Cr}_{2} \mathrm{O}_{3}$ is controlled by external mass transfer. This is in contradiction with the data of Figure 3. It seems that the reaction path changes at about $750{ }^{\circ} \mathrm{C}$. Figure 1 shows that the reaction products could be either $\mathrm{CrCl}_{3}$ or $\mathrm{CrCl}_{4}$ at temperatures lower and higher than $750{ }^{\circ} \mathrm{C}$, respectively. This may explain the change of the value of the shape factor in the temperature range of 700 ${ }^{\circ} \mathrm{C}$ to $800{ }^{\circ} \mathrm{C}$ although no direct experimental measurements are available.

\section{Apparent reaction order with respect to $\mathrm{Cl}_{2}$}

To determine the effect of $\mathrm{Cl}_{2}$ partial pressure on the reaction rate, a series of isotherms is performed at $800{ }^{\circ} \mathrm{C}$ using a $\mathrm{Cl}_{2}+\mathrm{N}_{2}$ gas mixture with a gas velocity of $50 \mathrm{~cm} / \mathrm{min}$. The chlorine partial pressure was varied from 0.10 to $1.00 \mathrm{~atm}$. The weight loss evolution versus time for each isotherm is shown in Figure 7 (a). The mathematical fitting of this figure's data is plotted in Figure 7 (b) for $\mathrm{X}$ as a function of time. The average correlation coefficient is about 0.999. This indicates that the chlorination mechanism of $\mathrm{Cr}_{2} \mathrm{O}_{3}$ is the same within a chlorine partial pressure of 0.1 to $1 \mathrm{~atm}$. The slope of curve of Figure 8 indicates that the reaction order with respect to $\mathrm{Cl}_{2}{ }^{\prime} \mathrm{Cl}_{2}$ ' is $1.23 \pm 0.04$. 
C. Kinetics of Oxychlorination of $\mathrm{Cr}_{2} \mathrm{O}_{3}$ by $\mathrm{Cl}_{2}+\mathrm{O}_{2}$.

1. Effect of gas flow rate

This effect was studied at $1000{ }^{\circ} \mathrm{C}$ using a gas mixture containing $\mathrm{Cl}_{2}+\mathrm{O}_{2}\left(\mathrm{Cl}_{2} / \mathrm{O}_{2}=4\right)$ during the oxychlorination of chromium oxide. The evolution of reaction rate as a function of gas velocity is illustrated in Figure 9. The reaction rate is independent from the gas flow rate for a linear velocity of the reactive gases higher than $24.8 \mathrm{~cm} / \mathrm{min}$. For this reason, a gas flow rate having $\mathrm{V}_{\mathrm{g}}=33 \mathrm{~cm} / \mathrm{min}(40 \mathrm{~L} / \mathrm{h})$ is used for further experiments on oxychlorination of $\mathrm{Cr}_{2} \mathrm{O}_{3}$.

\section{Effect of $\mathrm{Cl}_{2} /\left(\mathrm{Cl}_{2}+\mathrm{O}_{2}\right)$ ratio}

To get an insight of the oxychlorination mechanism of $\mathrm{Cr}_{2} \mathrm{O}_{3}$, a series of experiments is carried out at $800{ }^{\circ} \mathrm{C}$ with $\mathrm{Cl}_{2} /\left(\mathrm{Cl}_{2}+\mathrm{O}_{2}\right)$ molar ratio varying from 0 to 1.0 . The gas velocity was kept constant and equal to $33 \mathrm{~cm} / \mathrm{min}$. Figure 10 shows the evolution of the reaction rate versus $\mathrm{Cl}_{2} /\left(\mathrm{Cl}_{2}+\mathrm{O}_{2}\right)$ molar ratio. The oxychlorination rate passes by a maximum corresponding to a $\mathrm{Cl}_{2} /\left(\mathrm{Cl}_{2}+\mathrm{O}_{2}\right)$ molar ratio at about 0.8 . This value corresponds to a molar ratio of $\mathrm{Cl}_{2} / \mathrm{O}_{2}$ equal to 4 . These results show that the chlorination of chromium (III) oxide with $\mathrm{Cl}_{2}+\mathrm{O}_{2}$ mixture takes place according to reaction 5 involving the formation of $\mathrm{CrO}_{2} \mathrm{Cl}_{2}$ (g) as the main reaction product.

In an attempt to confirm the $\mathrm{CrO}_{2} \mathrm{Cl}_{2}$ (g) formation, a few experiments were performed with 2 grams of $\mathrm{Cr}_{2} \mathrm{O}_{3}$ sample between $800{ }^{\circ} \mathrm{C}$ and $1000{ }^{\circ} \mathrm{C}$ for a reaction time of 2 hours. The experiments are carried out using a horizontal set ${ }^{[20]}$ and a gas mixture having $\mathrm{Cl}_{2} / \mathrm{O}_{2}$ molar ratio equal to 4 . The exhaust gases were successively cooled at $25{ }^{\circ} \mathrm{C}$ and $-35^{\circ} \mathrm{C}$. No solid condensate is observed by cooling the exhaust gases at $25{ }^{\circ} \mathrm{C}$ indicating the absence of chromium chlorides' formation. However, cooling the vapor phase to $-35^{\circ} \mathrm{C}$ leads to the formation of a red liquid. This liquid decomposes in air and explodes with alcohol. The qualitative chemical analysis indicates that the solid generated by the decomposition of this liquid is essentially chromium oxide. The properties of the obtained red liquid are in good agreement with those reported by reference [10] for the $\mathrm{CrO}_{2} \mathrm{Cl}_{2}(\mathrm{~g})$.

\section{Apparent reaction order with respect to $\mathrm{Cl}_{2}+\mathrm{O}_{2}$}

The experiments for determining the apparent reaction order with respect to $\mathrm{Cl}_{2}+\mathrm{O}_{2}$ were performed at $800{ }^{\circ} \mathrm{C}$. The $\mathrm{Cl}_{2} / \mathrm{O}_{2}$ molar ratio is kept constant and equal to 4 in the gas mixture, while the partial pressure of $\mathrm{Cl}_{2}+\mathrm{O}_{2}$ is varied from 0.38 to 1.00 atm by diluting the gas mixture with nitrogen. The evolution of the reaction rate as a function of $\mathrm{Cl}_{2}+\mathrm{O}_{2}$ partial pressure is shown by Figure 11. The apparent reaction order ' $\mathrm{n}\left(\mathrm{Cl}_{2}+\mathrm{O}_{2}\right)$ ' deduced from these data is $1.29 \pm 0.01$. 
4. Apparent reaction orders with respect to $\mathrm{Cl}_{2}$ and to $\mathrm{O}_{2}$

The effect of $\mathrm{Cl}_{2}$ and $\mathrm{O}_{2}$ partial pressure is examined at $800{ }^{\circ} \mathrm{C}$. Two series of tests were carried out using $\mathrm{Cl}_{2}+\mathrm{O}_{2}+\mathrm{N}_{2}$ with a flow rate of $33 \mathrm{~cm} / \mathrm{min}$. The first series of tests is performed by keeping the oxygen partial pressure constant $(0.33 \mathrm{~atm})$ and varying the chlorine partial pressure from 0.14 to 0.52 atm. The second one is conducted using a constant chlorine partial pressure $(0.33 \mathrm{~atm})$ and varying the oxygen partial pressure from 0.14 to $0.52 \mathrm{~atm}$.

Figures 12 and 13 trace the evolution of natural logarithm of reaction rates as a function of that of chlorine and oxygen partial pressures, receptively. The apparent reaction orders with respect to chlorine ' $\mathrm{Cl}_{2}$ ' and to oxygen ' $\mathrm{O}_{2}$ ' are obtained by the linearization of data of these figures. The value of ' $\mathrm{n}_{2}{ }_{2}$ and ' $\mathrm{n}_{2}$ ' are $1.08 \pm 0.02$ and $0.23 \pm 0.01$, respectively. This confirms that the presence of oxygen enhances the reaction rate. This observation confirms the formation of $\mathrm{CrO}_{2} \mathrm{Cl}_{2}(\mathrm{~g})$ as described by Eq 5. On the other hand, one may underline that the global reaction order is almost equal to the algebraic sum of the

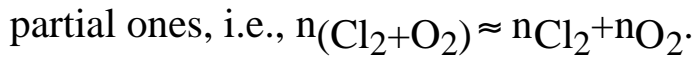

\section{Effect of temperature}

This effect on the oxychlorination of chromium (III) oxide is investigated by isothermal measurements between $540{ }^{\circ} \mathrm{C}$ and $1000{ }^{\circ} \mathrm{C}$. $\mathrm{A} \mathrm{Cl}_{2}+\mathrm{O}_{2}\left(\mathrm{Cl}_{2} / \mathrm{O}_{2}=4\right)$ gas mixture having a total flow rate of $33 \mathrm{~cm} / \mathrm{min}$ is used. The evolution of the sample's pct weight loss versus time for different temperatures is shown in Figures 14 (a) and (b). At $550{ }^{\circ} \mathrm{C}$, about 45 pct of the sample is chlorinated for a reaction time of 500 minutes while at $950{ }^{\circ} \mathrm{C}$ only 25 minutes are necessary to attain the same reaction extent. The Arrhenius plot of oxychlorination of $\mathrm{Cr}_{2} \mathrm{O}_{3}$ is traced in Figure 15 and presents a classical evolution of a solid-gas reaction kinetics as a function of temperature. ${ }^{[19]}$ The apparent activation energy changes from $87 \mathrm{~kJ} / \mathrm{mol}$, below $650{ }^{\circ} \mathrm{C}$, to $46 \mathrm{~kJ} / \mathrm{mol}$ for temperatures higher than $700{ }^{\circ} \mathrm{C}$.

Figure 16 illustrates the evolution of specific surface area of partially oxychlorinated samples $(\mathrm{X} \approx$ 0.27) of $\mathrm{Cr}_{2} \mathrm{O}_{3}$ as a function of temperature. The samples' specific surface area decreases sharply for temperatures higher than $600{ }^{\circ} \mathrm{C}$ and this phenomenon could be related to the decrease of $\mathrm{E}_{\mathrm{a}}$ that occurs at about $650{ }^{\circ} \mathrm{C}$.

Mathematical fitting of the experimental data of Figure 14 is examined using Eqs 11 to 14 . The plots of the best fitting are represented in Figures 17 (a) and (b). At temperatures lower than $650{ }^{\circ} \mathrm{C}$, equation 
14 applies to the experimental data with an average correlation coefficient of 0.998 (Fig. 17 a). The values of apparent activation energy coupled with this equation indicate that the rate-controlling step of overall process could be the chemical reaction. The data of experiments carried out between $700{ }^{\circ} \mathrm{C}$ and $1000{ }^{\circ} \mathrm{C}$ are linearized by using Eq 13 giving 1-(1-X) ${ }^{1 / 2}$ versus time (Fig. 17 b) with a correlation coefficient higher than 0.999. At temperatures higher than $700{ }^{\circ} \mathrm{C}$, the decrease of the specific surface area could be related to the modification of shape factor of grains and to the decrease of the value of the apparent activation energy.

Figures 18 (a), (b) and (c) summarize plots of Eq 13 of the data obtained during the oxychlorination of $\mathrm{Cr}_{2} \mathrm{O}_{3}$ at $800{ }^{\circ} \mathrm{C}$ for various partial pressures of $\mathrm{Cl}_{2}+\mathrm{O}_{2}, \mathrm{Cl}_{2}$ and $\mathrm{O}_{2}$, respectively. The average correlation coefficient of data linearization for $0 \leq X \leq 0.8$ is higher than 0.999 . It can be concluded that the reaction mechanism is not affected by the change of the partial pressures of reactive gases in the pressure range investigated at $800{ }^{\circ} \mathrm{C}$.

The effect of temperature on the chlorination and oxychlorination of chromium (III) oxide is compared in Figure 19. At $500{ }^{\circ} \mathrm{C}$, the reactivity of $\mathrm{Cr}_{2} \mathrm{O}_{3}$ towards $\mathrm{Cl}_{2}+\mathrm{N}_{2}$ is low and the reaction rate is about 0.01 pct weight loss per minute. On the other hand, the oxychlorination rate of $\mathrm{Cr}_{2} \mathrm{O}_{3}$ is higher than that of its chlorination specially at low temperatures.

The oxychlorination of the chromium oxide bearing materials with $\mathrm{Cl}_{2}+\mathrm{O}_{2}\left(\mathrm{Cl}_{2} / \mathrm{O}_{2}=4\right)$ at temperatures higher than $800{ }^{\circ} \mathrm{C}$ could be suggested for the separation of chromium compounds from these solids.

\section{CONCLUSIONS}

Analysis of the thermodynamic data of the possible chlorination reactions of chromium oxide shows that the most probable reaction product of $\mathrm{Cr}_{2} \mathrm{O}_{3}$ chlorination is chromium(VI) oxychloride.

The reaction of $\mathrm{Cr}_{2} \mathrm{O}_{3}$ with a $\mathrm{Cl}_{2}+\mathrm{N}_{2}$ and $\mathrm{Cl}_{2}+\mathrm{O}_{2}$ gas mixture starts at temperatures higher than 550 ${ }^{\circ} \mathrm{C}$. The reactivity of chromium oxide towards the oxychlorinating gas mixture is higher than that of the chlorinating gas mixture. The rate of volatilization and/or reaction of chromium trichloride, with the two chlorinating gas mixtures, is higher than that of its generation during the chlorination of chromium (III) 
oxide and justifies the use of TGA to study the chlorination kinetics of $\mathrm{Cr}_{2} \mathrm{O}_{3}$.

At $800{ }^{\circ} \mathrm{C}$, the apparent reaction order with respect to chlorine is about 1.23 . Between $550{ }^{\circ} \mathrm{C}$ and $1000{ }^{\circ} \mathrm{C}$, the chlorination of $\mathrm{Cr}_{2} \mathrm{O}_{3}$ by $\mathrm{Cl}_{2}+\mathrm{N}_{2}$ proceeds with an apparent activation energy of $86 \mathrm{~kJ} / \mathrm{mol}$. Mathematical fitting of the experimental data suggests that the reaction bath changes at about $650{ }^{\circ} \mathrm{C}$. At temperatures lower than $650{ }^{\circ} \mathrm{C}$, the shrinking sphere model is the most appropriate for describing the reaction's kinetics.

The apparent activation energy of $\mathrm{Cr}_{2} \mathrm{O}_{3}$ oxychlorination is about $87 \mathrm{~kJ} / \mathrm{mol}$ at temperatures lower than $650{ }^{\circ} \mathrm{C}$ and decreases to $46 \mathrm{~kJ} / \mathrm{mol}$ for temperatures higher than $700{ }^{\circ} \mathrm{C}$. The mathematical modeling of the experimental data obtained during the oxychlorination of chromium oxide indicates a change of the shape factor from 3 to 2 around $650{ }^{\circ} \mathrm{C}$. These results could be attributed to the sharp decrease of the specific surface area of the $\mathrm{Cr}_{2} \mathrm{O}_{3}$ sample, at about $600{ }^{\circ} \mathrm{C}$, during its oxychlorination.

The oxychlorination reaction rate of $\mathrm{Cr}_{2} \mathrm{O}_{3}$ by $\mathrm{Cl}_{2}+\mathrm{O}_{2}$ passes by a maximum for a gas mixture having a molar ratio of $\mathrm{Cl}_{2} / \mathrm{O}_{2}$ equal to 4 . The reaction order with respect to chlorine, oxygen and $\mathrm{Cl}_{2}+\mathrm{O}_{2}$ is $1.08,0.23$ and 1.29 , respectively. The overall reaction order is almost equal to the algebraic sum of the fractional ones. These results confirm the formation of chromium oxychloride as the final reaction's product of $\mathrm{Cr}_{2} \mathrm{O}_{3}$ oxychlorination. Data analysis indicates that the reaction mechanism is independent of the composition of the oxychlorinating gas mixture in the explored range.

These results suggest that the separation of chromium compounds from chromium bearing materials is possible using an oxychlorinating gas mixture at temperatures equal or higher than $800{ }^{\circ} \mathrm{C}$.

\section{ACKNOWLEDGMENTS}

This work was performed in the frame of contract $\mathrm{N}^{\circ}$ BRE2-CT92-0173 thanks to the financial support of the European Union (DG-XII). The authors thank Drs. H. L. Schmidt for discussion, suggestion and help.

They also would like to thank Drs. J. C. Mugica (INASMET, San Sebastian, Spain) and M. Coelho (INETI, Lisbon, Portugal) for technical discussions. Authors are indebted to A. Bonazébi, M. Djona, N. Menad and N. Mirghaffari for discussions and help on different subjects and to Mrs. C. Tanchel for technical and administrative support. 


\section{REFERENCES}

1. M.-Ch. Meyer-Joly: Ph. D. Thesis, Institut National Polythechnique de Lorraine, Laboratoire Environnement et Mineralurgie, Nancy, France, September 1988.

2. E. Allain: Ph. D. Thesis, Université de Nancy I, France, June 1993.

3. M. Djona: Ph. D. Thesis, Institut National Polythechnique de Lorraine, Laboratoire Environnement et Mineralurgie, Nancy, France, January 1994.

4. M. Djona, I. Gaballah, J.C. Múgica and R. Solozábal: Proceeding of the $3^{\text {rd }}$ International Symposium on Recycling of Metals and Engineered Materials, 11/95, Clear Point, AL, USA, Ed. by P.B. Queneau and R.D. Peterson, Publ. by the TMS, 1995, pp. 405-424.

5. N. Kanari: Ph. D. Thesis, Institut National Polythechnique de Lorraine, Laboratoire Environnement et Mineralurgie, Nancy, France, November 1995.

6. N. Kanari and I. Gaballah: Proceeding of the 126th TMS Annual Meeting, February 1997, Orlando, Florida, USA, Edited by B. Mishra, 1997, pp. 57-71.

7. M. Djona, E. Allain and I. Gaballah: Metall. Trans. B, 1995, vol. 26B, pp. 703-710.

8. I. Gaballah, M. Djona and E. Allain: Metall. Trans. B, 1995, vol. 26B, pp. 711-718.

9. E. Allain, M. Djona and I. Gaballah: Metall. Trans. B, 1997, vol. 28B, pp 223-233.

10. P. Pascal: Nouveau traité de chimie minérale, Masson et Cie, Éditeurs, Paris, 1959, Tome XIV, pp. 150-153.

11. I.S. Morozov and G.F. Fefelova: Zh. Prikl. Khim. (Leningrad), 1971, vol. 44 (5), pp. 1161-1163.

12. N. Sano and G.R. Belton: Metall. Trans., 1974, vol. 5 (10), pp. 2151-2154.

13. K. Reinhold and K. Hauffe: J. Electrochem. Soc., 1977, vol. 124 (6), pp. 875-883.

14. V. Plies: Z. anorg. allg. Chem., 1991, 602, pp. 97-104.

15. N.S. Jacobson, M.J. McNallan and Y.Y. Lee: Metall. Trans. A, 1989, vol. 20A (8), pp. 1566-1568.

16. M.J. McNallan, N.S. Jacobson, Y.Y. Lee and Y.W. Chang: In Proceedings-Electrochemical Society, 1990, vol. 90-18, pp. 51-62.

17. I. Barin, Thermochemical data of pure substances, 1989, Part I, VCH.

18. Anonymous: Handbook of Chemistry and Physics, 74th edition, Editor-in-Chief D.R. Lide, CRC Press, Florida, USA, 1993-94, p. 4-53.

19. J. Szekely, J.W. Evans and H.Y. Sohn: in Gas-Solid Reactions, Academic Press, New York, NY. 1976, pp. 68-70, 73-88, 109-31 and 232-35.

20. I. Gaballah and M. Djona, Extractive Metallurgy of Copper, Nickel and Cobalt, Proceeding of the Paul E. Queneau International Symposium, 2/1993, Denver, CO, USA Volume I : Fundamental Aspects, Edited by R. G. Reddy and R. N. Weizenbach, Published by the Minerals, Metals \& Materials Society, 1993, pp. 1253-68. 


\section{FIGURE CAPTIONS}

Figure 1 : Standard free energy change of $\mathrm{Cr}_{2} \mathrm{O}_{3}$ chlorination reactions as a function of temperature.

Figure 2 : TG analysis of $\mathrm{Cr}_{2} \mathrm{O}_{3}$ and $\mathrm{CrCl}_{3}$ treatment in $\mathrm{Cl}_{2}+\mathrm{N}_{2}$ and $\mathrm{Cl}_{2}+\mathrm{O}_{2}$.

Figure 3 : Chlorination rate of $\mathrm{Cr}_{2} \mathrm{O}_{3}$ as a function of flow rate of the $\mathrm{Cl}_{2}+\mathrm{N}_{2}$ mixture.

Figure 4 : Isotherms of chlorination of $\mathrm{Cr}_{2} \mathrm{O}_{3}$ with $\mathrm{Cl}_{2}+\mathrm{N}_{2}$ for $(a) \mathrm{T} \leq 775{ }^{\circ} \mathrm{C}$ and $(b) \mathrm{T} \geq 800{ }^{\circ} \mathrm{C}$.

Figure 5 : Arrhenius plot of chlorination of $\mathrm{Cr}_{2} \mathrm{O}_{3}$ by $\mathrm{Cl}_{2}+\mathrm{N}_{2}$.

Figure 6 : Mathematical fitting of the chlorination data at $(a) \mathrm{T} \leq 700{ }^{\circ} \mathrm{C}$ using Eq. 14 and $(b) \mathrm{T} \geq 800$ ${ }^{\circ} \mathrm{C}$ using Eq. 12.

Figure 7 : Isotherms of chlorination of $\mathrm{Cr}_{2} \mathrm{O}_{3}$ (a) using different chlorine pressures and $(b)$ linearization of data using Equation 12.

Figure 8 : Apparent reaction order of $\mathrm{Cr}_{2} \mathrm{O}_{3}$ chlorination with respect to chlorine.

Figure 9 : Chlorination rate of $\mathrm{Cr}_{2} \mathrm{O}_{3}$ as a function of flow rate of the $\mathrm{Cl}_{2}+\mathrm{O}_{2}$ mixture.

Figure 10 : Effect of $\mathrm{Cl}_{2} /\left(\mathrm{Cl}_{2}+\mathrm{O}_{2}\right)$ molar ratio on the reaction rate of $\mathrm{Cr}_{2} \mathrm{O}_{3}$ oxychlorination.

Figure 11 : Apparent reaction order with respect to $\mathrm{Cl}_{2}+\mathrm{O}_{2}$.

Figure 12 : Apparent reaction order with respect to $\mathrm{Cl}_{2}$.

Figure 13 : Apparent reaction order with respect to $\mathrm{O}_{2}$.

Figure 14 : Isotherms of chlorination of $\mathrm{Cr}_{2} \mathrm{O}_{3}$ with $\mathrm{Cl}_{2}+\mathrm{O}_{2}$ for $(a) \mathrm{T} \leq 700$ and $(b) \mathrm{T} \geq 750{ }^{\circ} \mathrm{C}$.

Figure 15 : Arrhenius plot of chlorination of $\mathrm{Cr}_{2} \mathrm{O}_{3}$ by $\mathrm{Cl}_{2}+\mathrm{O}_{2}$.

Figure 16 : Evolution of the specific surface area of partially oxychlorinated samples $(\mathrm{X} \approx 0.27)$ of $\mathrm{Cr}_{2} \mathrm{O}_{3}$ as a function of temperature.

Figure 17 : Mathematical fitting of the oxychlorination data at $(a) \mathrm{T} \leq 650{ }^{\circ} \mathrm{C}$ and $(b) \mathrm{T} \geq 700{ }^{\circ} \mathrm{C}$ using Eqs 14 and 13, respectively.

Figure 18 : Mathematical fitting of the oxychlorination data at $800{ }^{\circ} \mathrm{C}$ using Eq 13

(a) for different $\left(\mathrm{Cl}_{2}+\mathrm{O}_{2}\right)$ partial pressure, $(b)$ for different $\mathrm{Cl}_{2}$ partial pressure and

(c) for different $\mathrm{O}_{2}$ partial pressure.

Figure 19 : Comparison of Arrhenius plots of chlorination and oxychlorination of $\mathrm{Cr}_{2} \mathrm{O}_{3}$. 


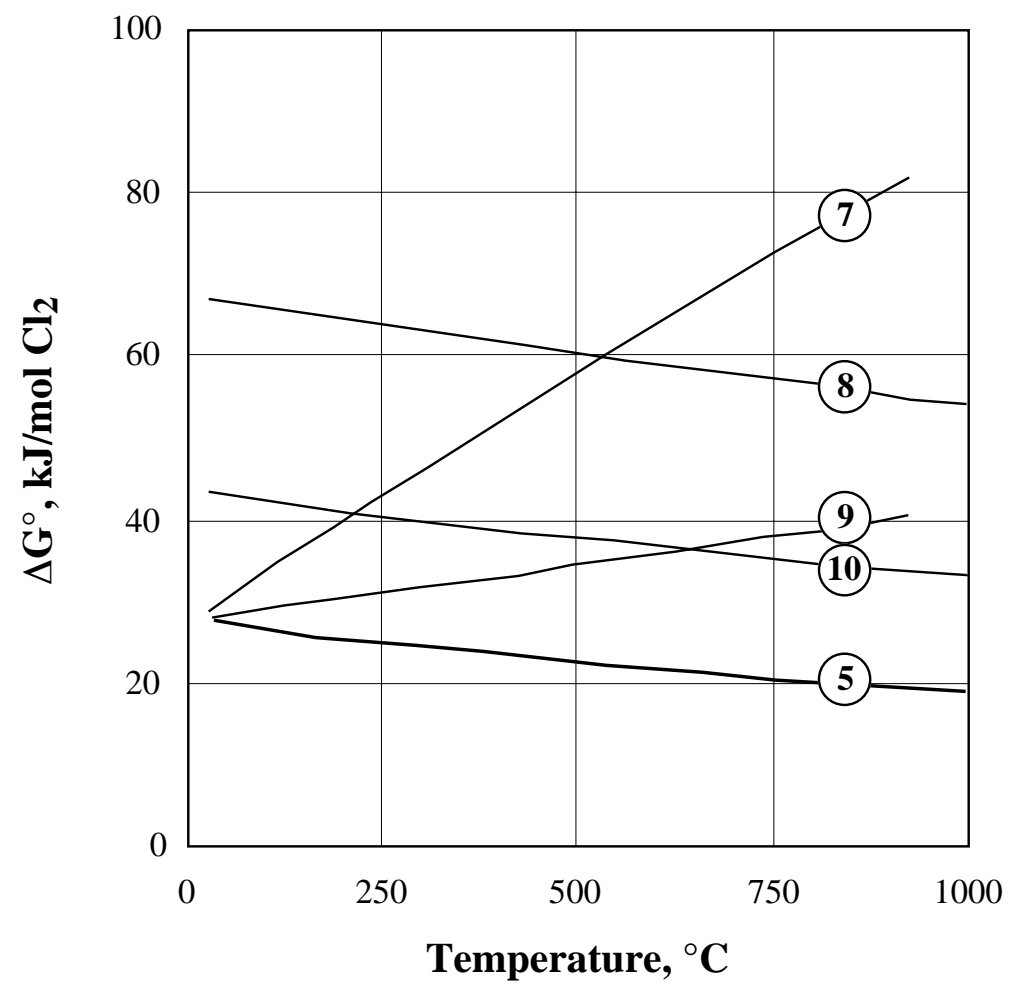

Fig. 1- Standard free energy changes of $\mathrm{Cr}_{2} \mathrm{O}_{3}$ chlorination reactions as a function of temperature.

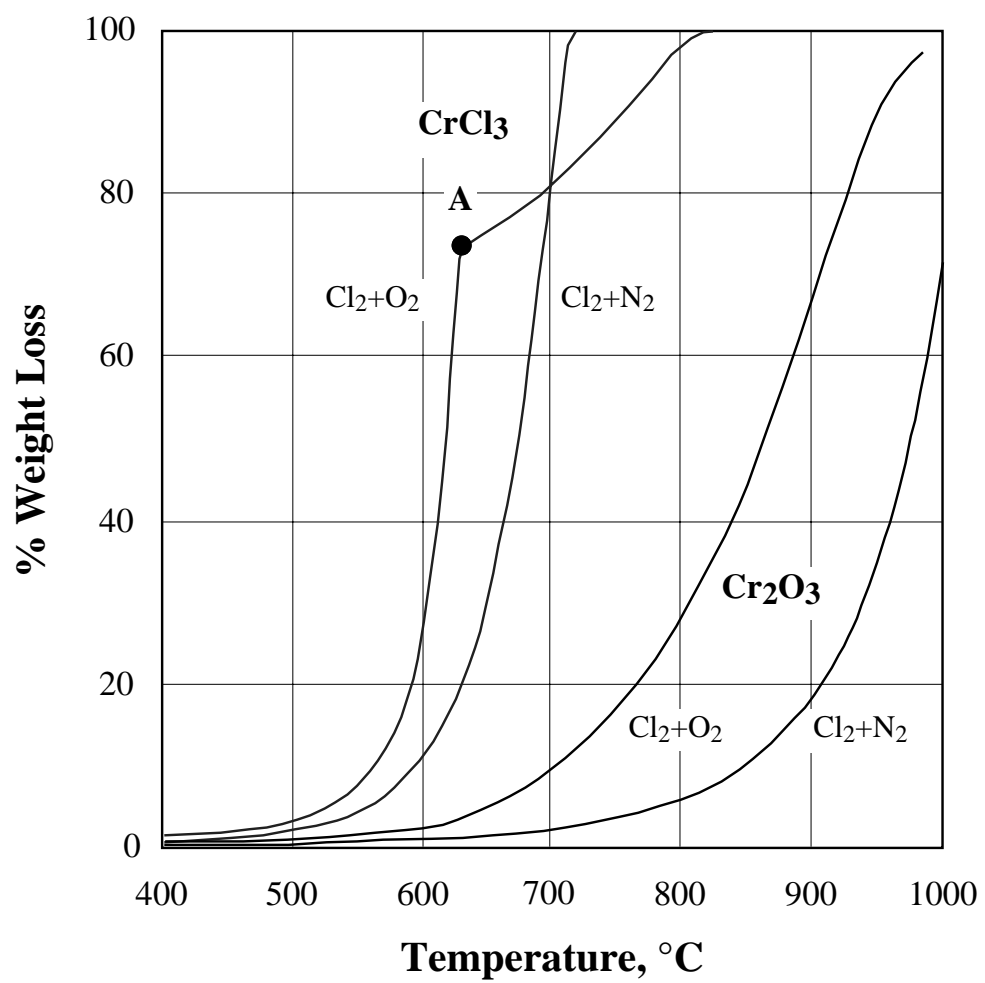

Fig. 2- TG analysis of $\mathrm{Cr}_{2} \mathrm{O}_{3}$ and $\mathrm{CrCl}_{3}$ treatment in $\mathrm{Cl}_{2}+\mathrm{N}_{2}$ and $\mathrm{Cl}_{2}+\mathrm{O}_{2}$. 
Total gas flow rate, $\mathrm{L} / \mathrm{h}$

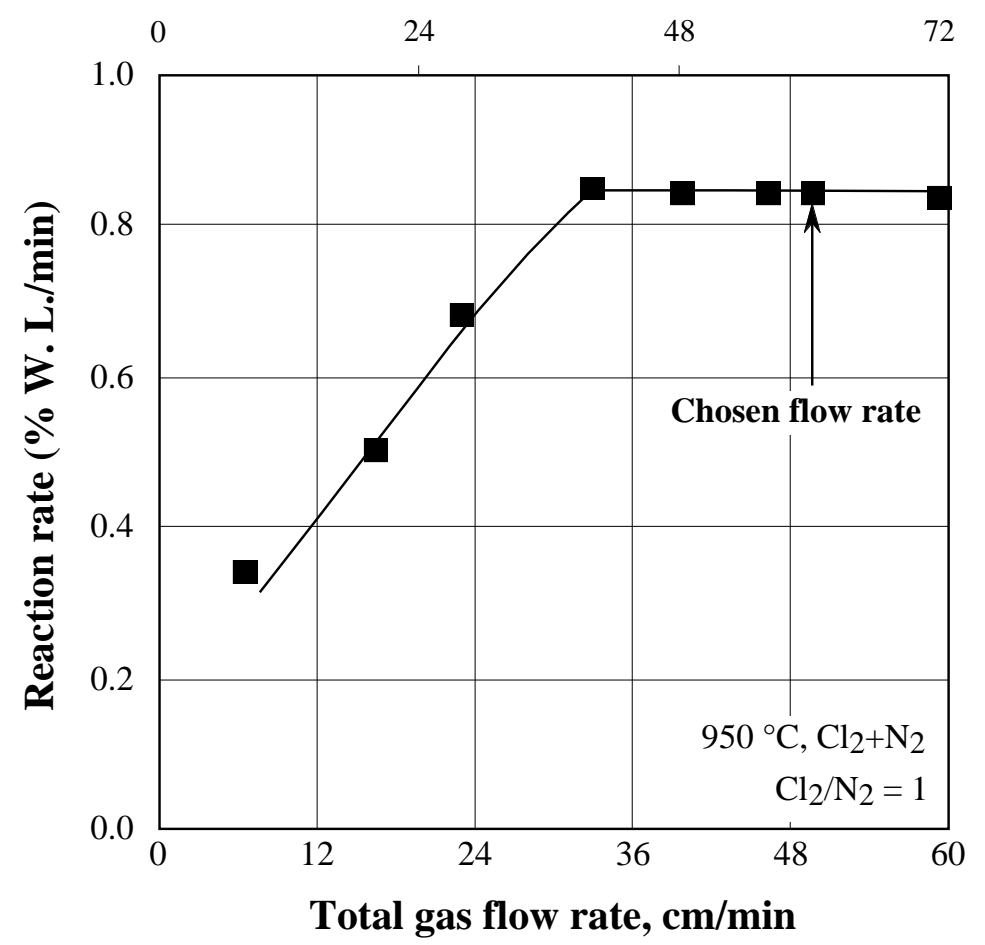

Fig. 3- Chlorination rate of $\mathrm{Cr}_{2} \mathrm{O}_{3}$ as a function of flow rate of the $\mathrm{Cl}_{2}+\mathrm{N}_{2}$ mixture.
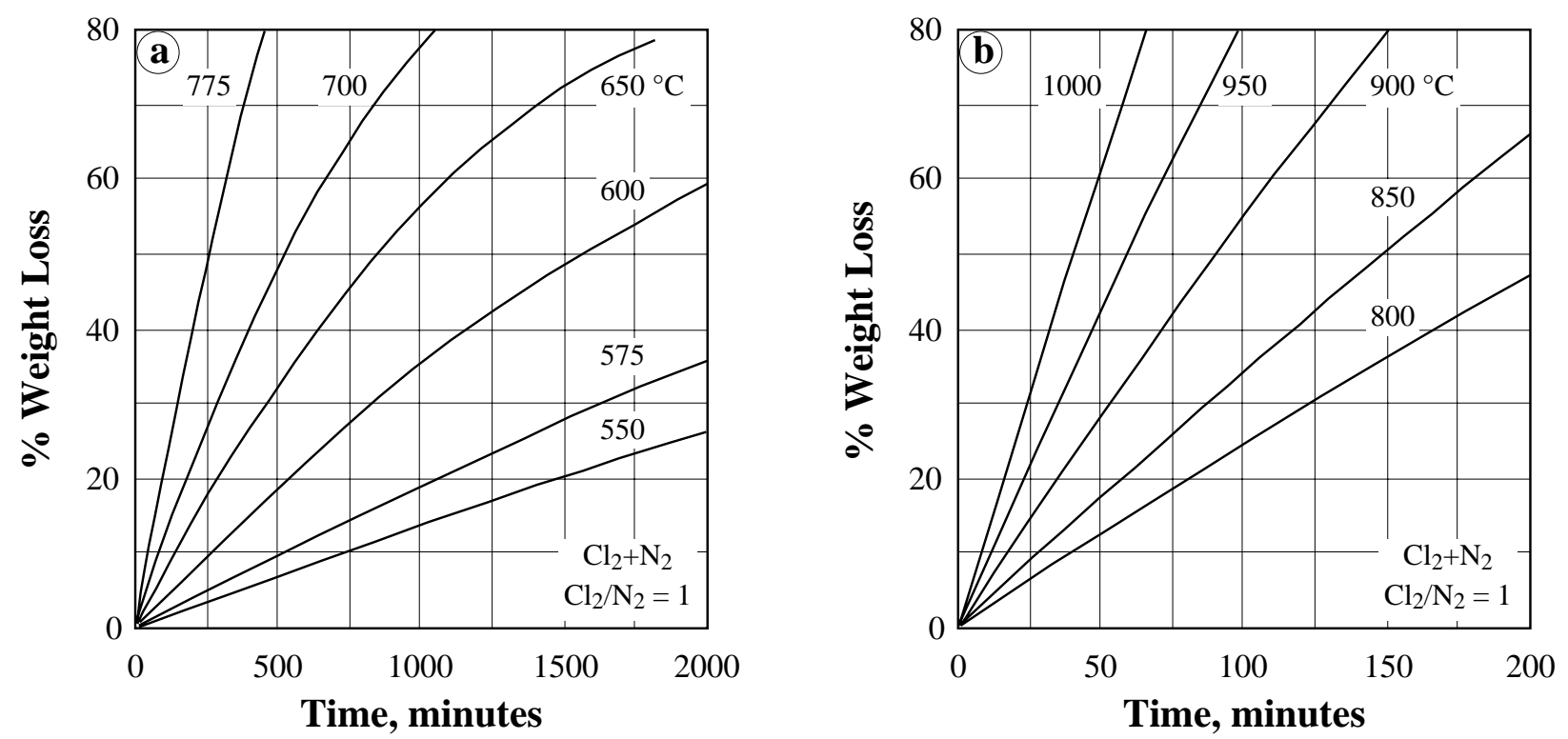

Fig. 4- Isotherms of chlorination of $\mathrm{Cr}_{2} \mathrm{O}_{3}$ with $\mathrm{Cl}_{2}+\mathrm{N}_{2}$ for $(a) \mathrm{T} \leq 775^{\circ} \mathrm{C}$ and $(b) \mathrm{T} \geq 800{ }^{\circ} \mathrm{C}$. 


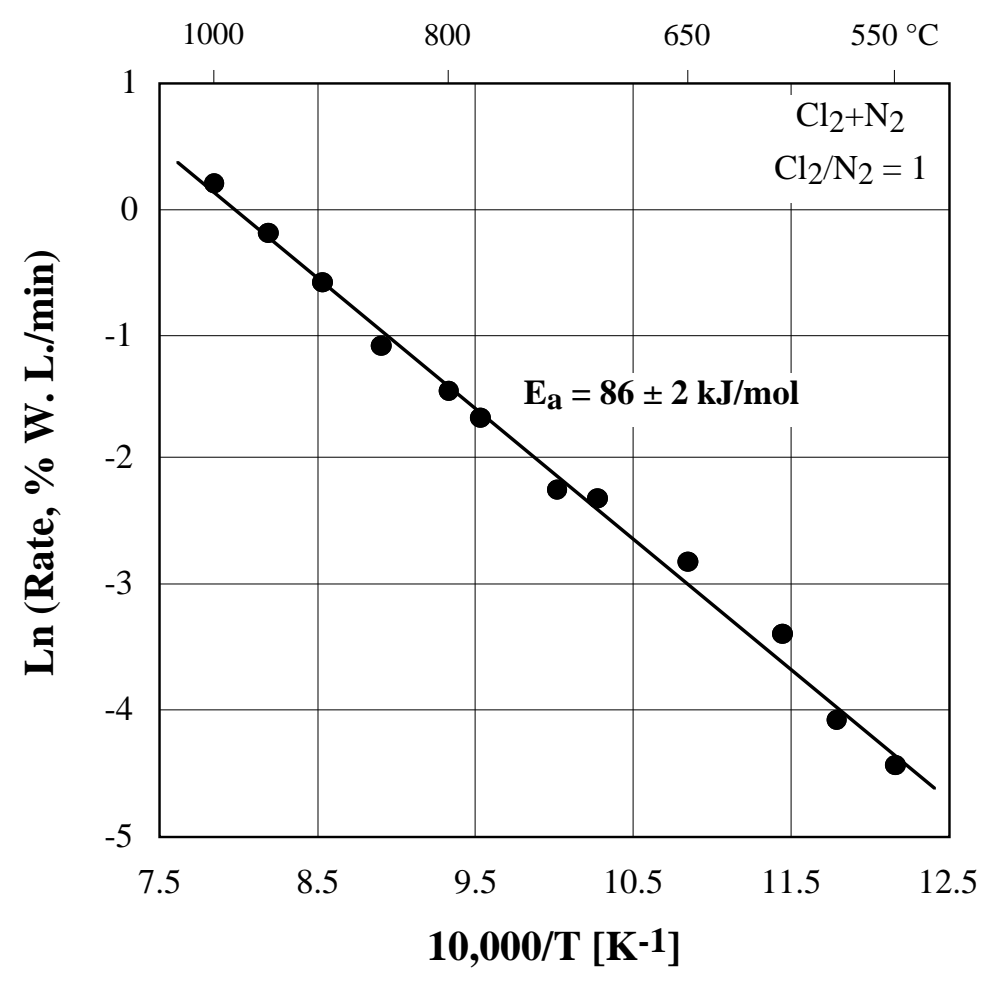

Fig. 5- Arrhenius plot of chlorination of $\mathrm{Cr}_{2} \mathrm{O}_{3}$ by $\mathrm{Cl}_{2}+\mathrm{N}_{2}$.
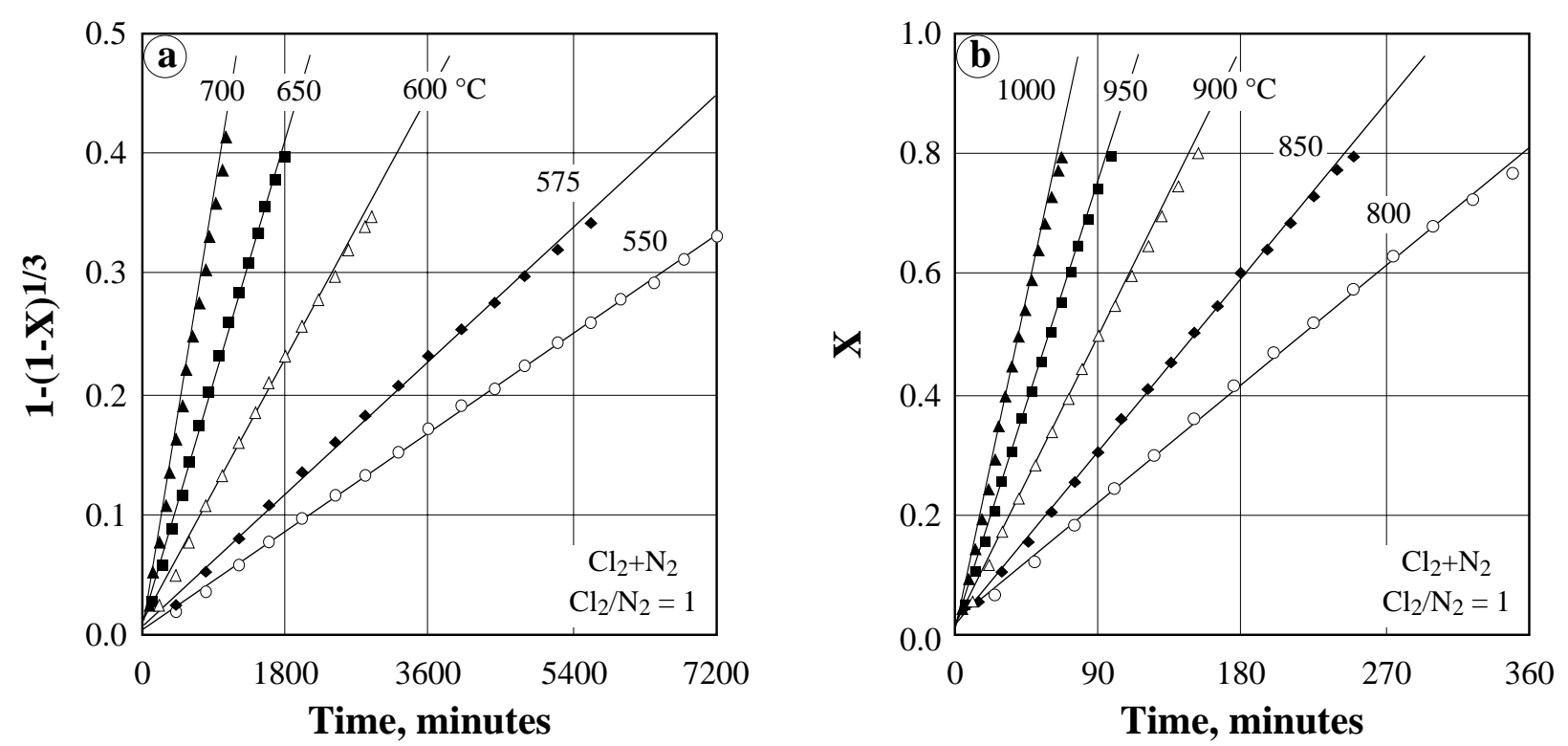

Fig. 6- Mathematical fitting of the chlorination data at $(a) \mathrm{T} \leq 700{ }^{\circ} \mathrm{C}$ using Eq. 14 and $(b) \mathrm{T} \geq 800^{\circ} \mathrm{C}$ using Eq. 12. 

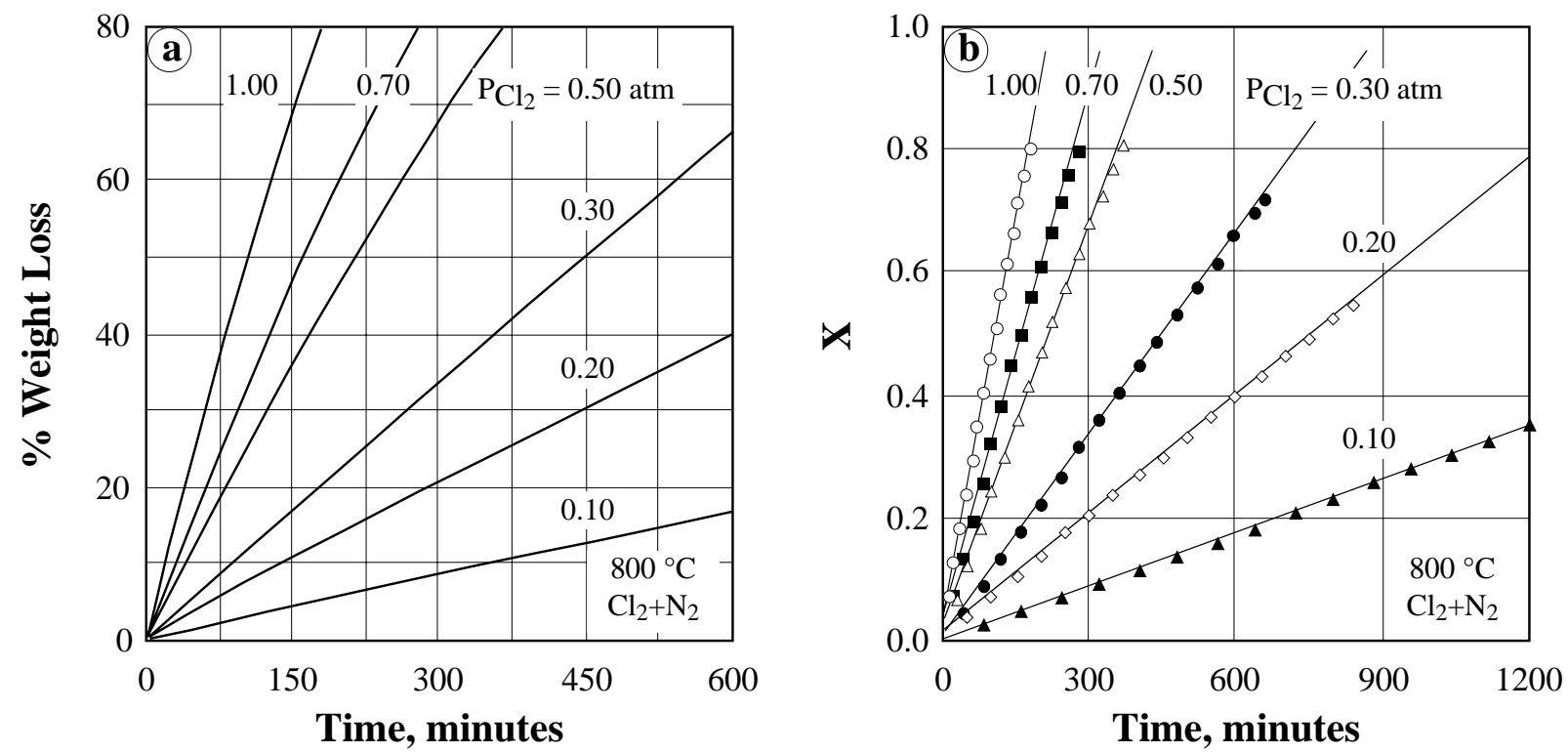

Fig. 7- Isotherms of chlorination of $\mathrm{Cr}_{2} \mathrm{O}_{3}(a)$ using different chlorine pressures and $(b)$ linearization of data using Equation 12.

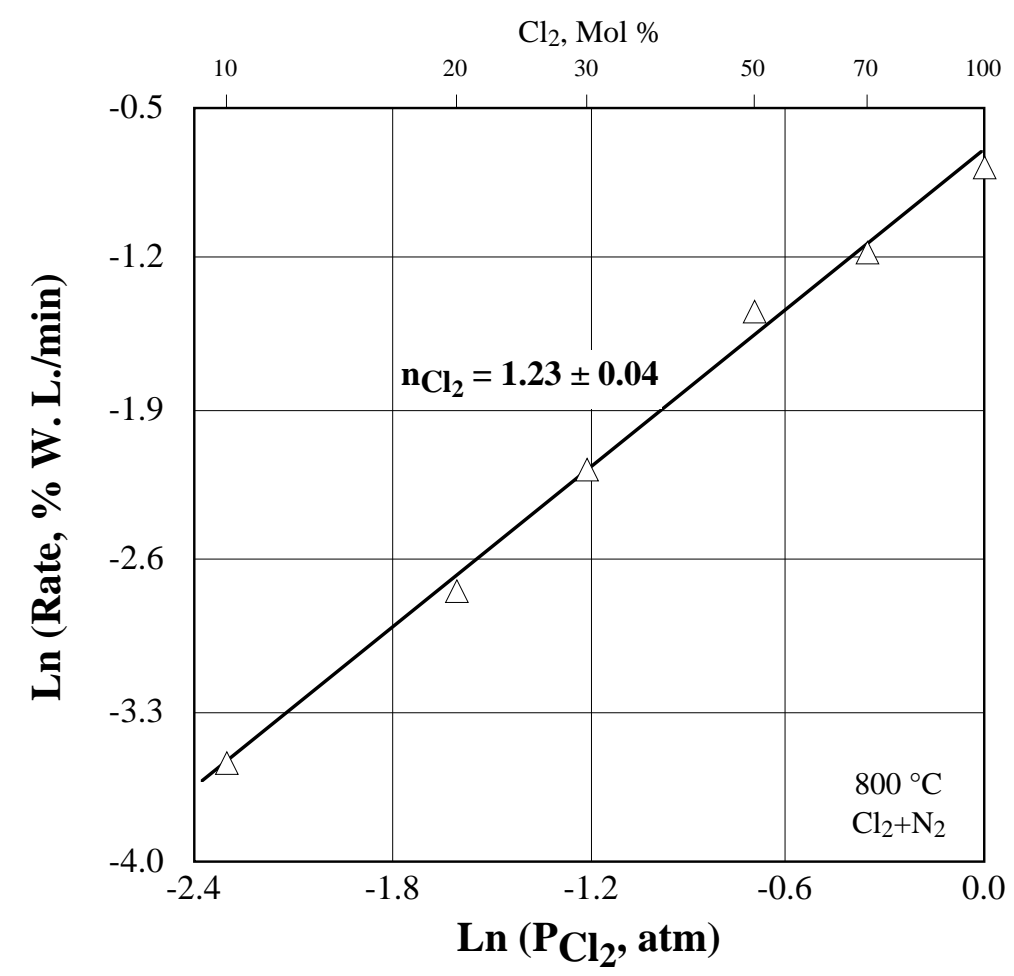

Fig. 8- Apparent reaction order of $\mathrm{Cr}_{2} \mathrm{O}_{3}$ chlorination with respect to chlorine. 


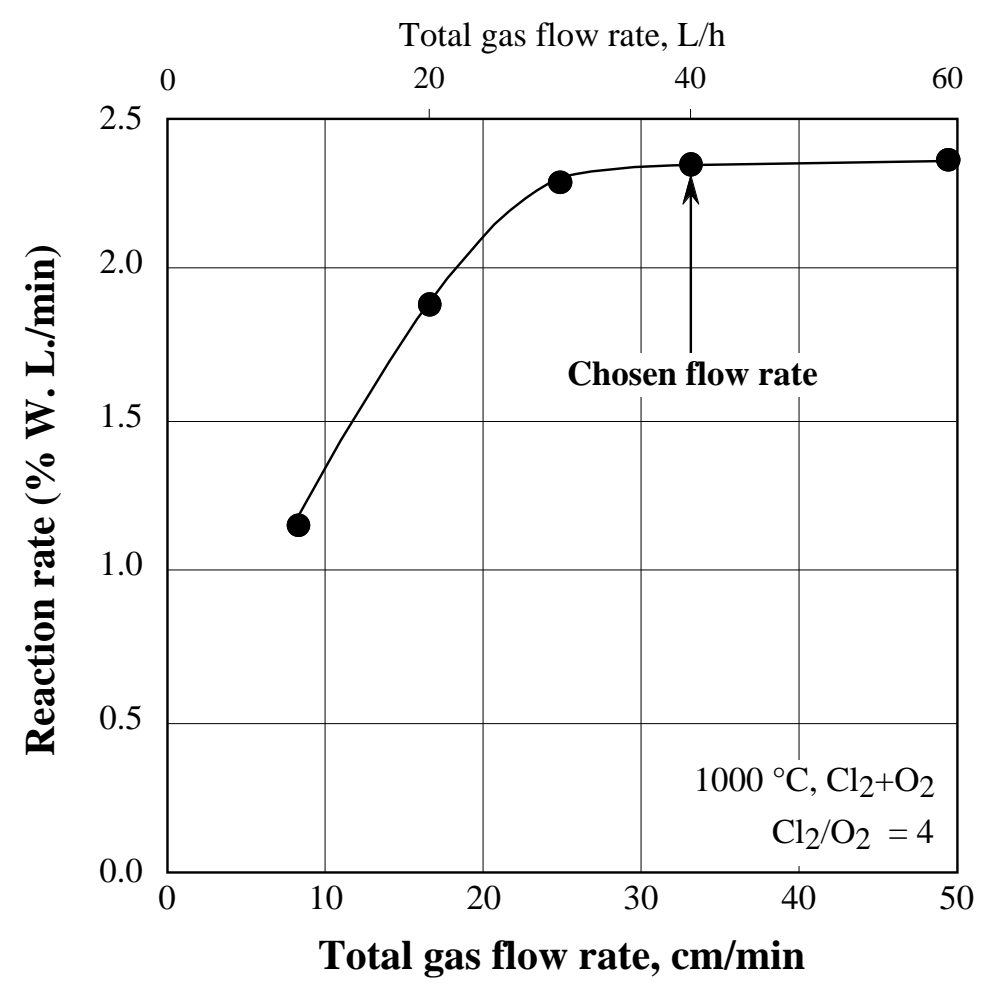

Fig. 9- Chlorination rate of $\mathrm{Cr}_{2} \mathrm{O}_{3}$ as a function of flow rate of the $\mathrm{Cl}_{2}+\mathrm{O}_{2}$ mixture.

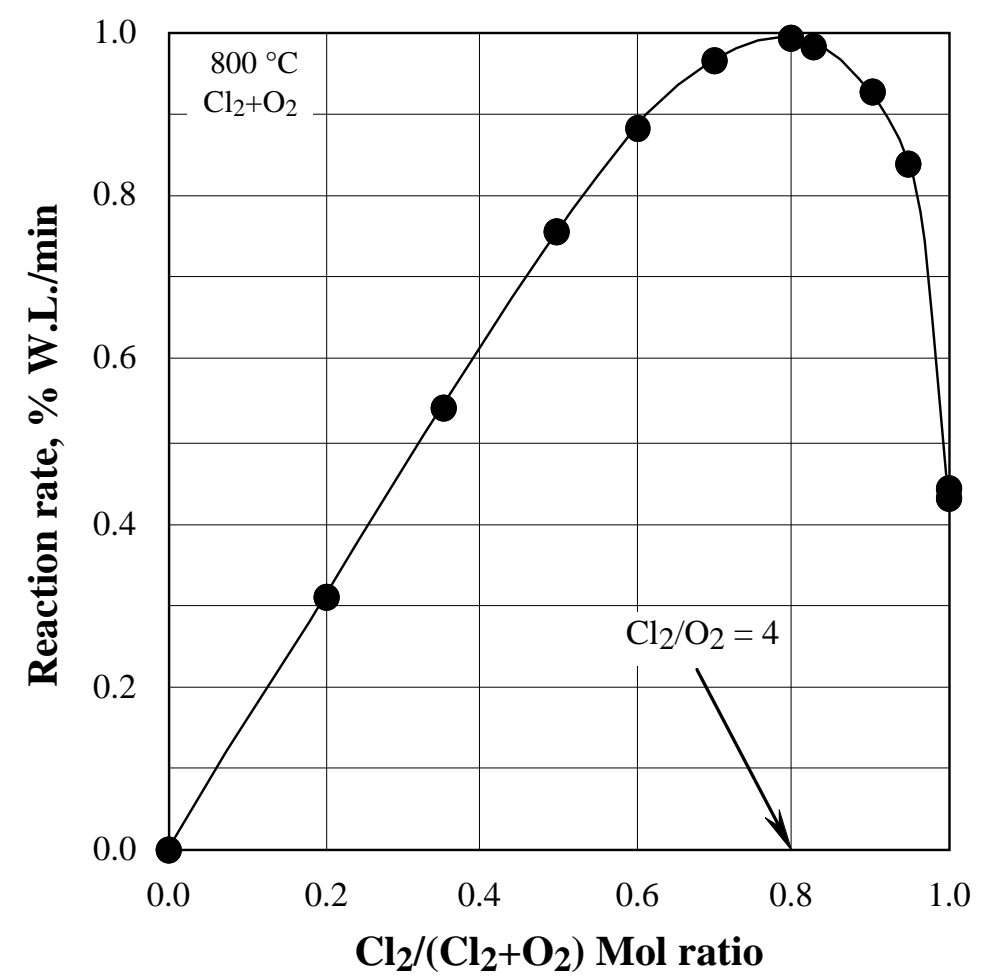

Fig. 10- Effect of $\mathrm{Cl}_{2} /\left(\mathrm{Cl}_{2}+\mathrm{O}_{2}\right)$ molar ratio on the reaction rate of $\mathrm{Cr}_{2} \mathrm{O}_{3}$ oxychlorination. 


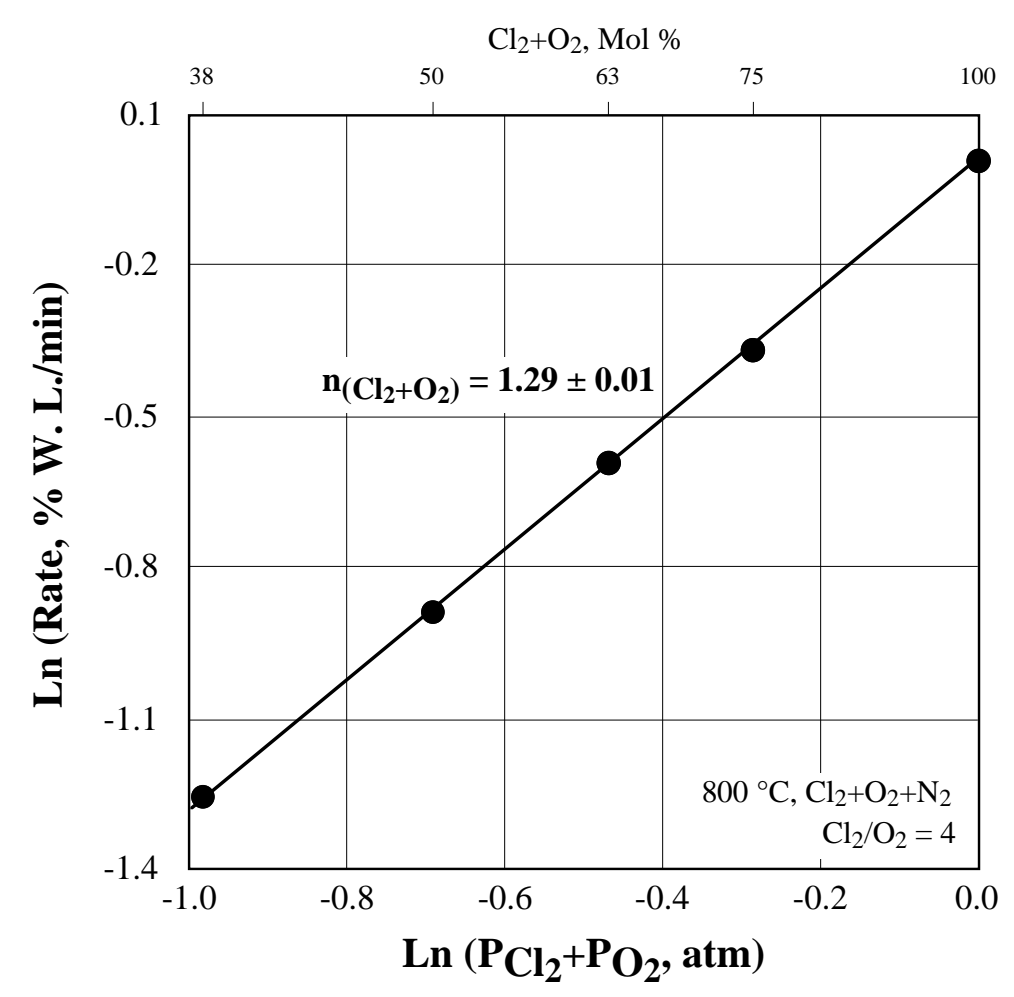

Fig. 11- Apparent reaction order with respect to $\mathrm{Cl}_{2}+\mathrm{O}_{2}$.

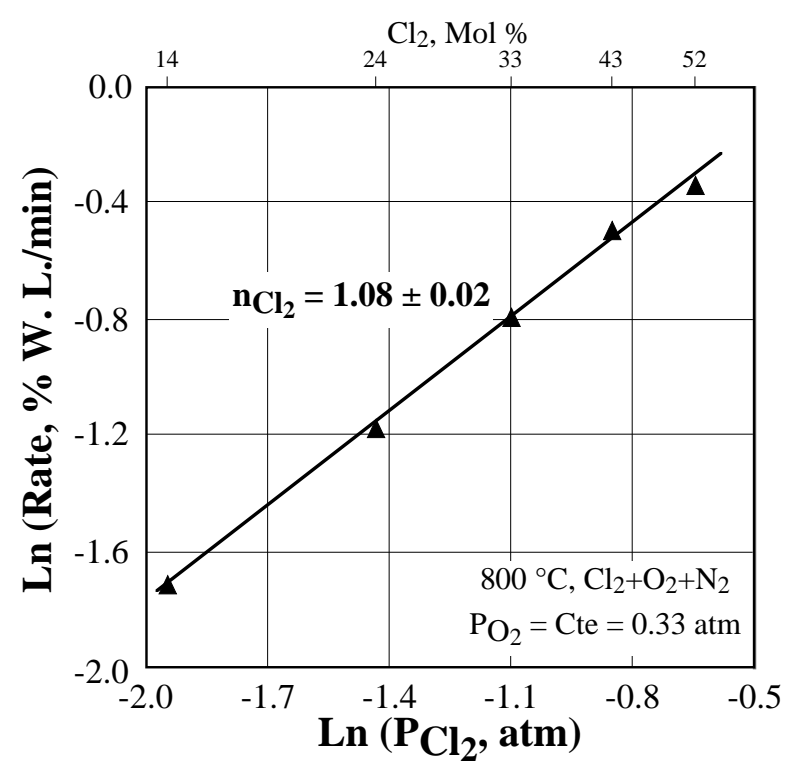

Fig. 12- Apparent reaction order with respect to $\mathrm{Cl}_{2}$.

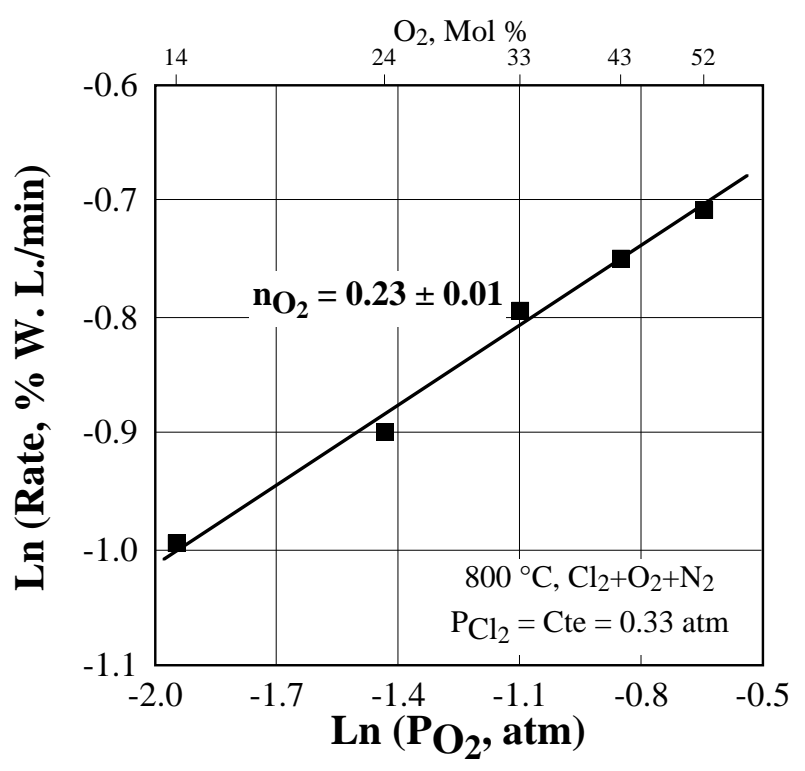

Fig. 13- Apparent reaction order with respect to $\mathrm{O}_{2}$. 

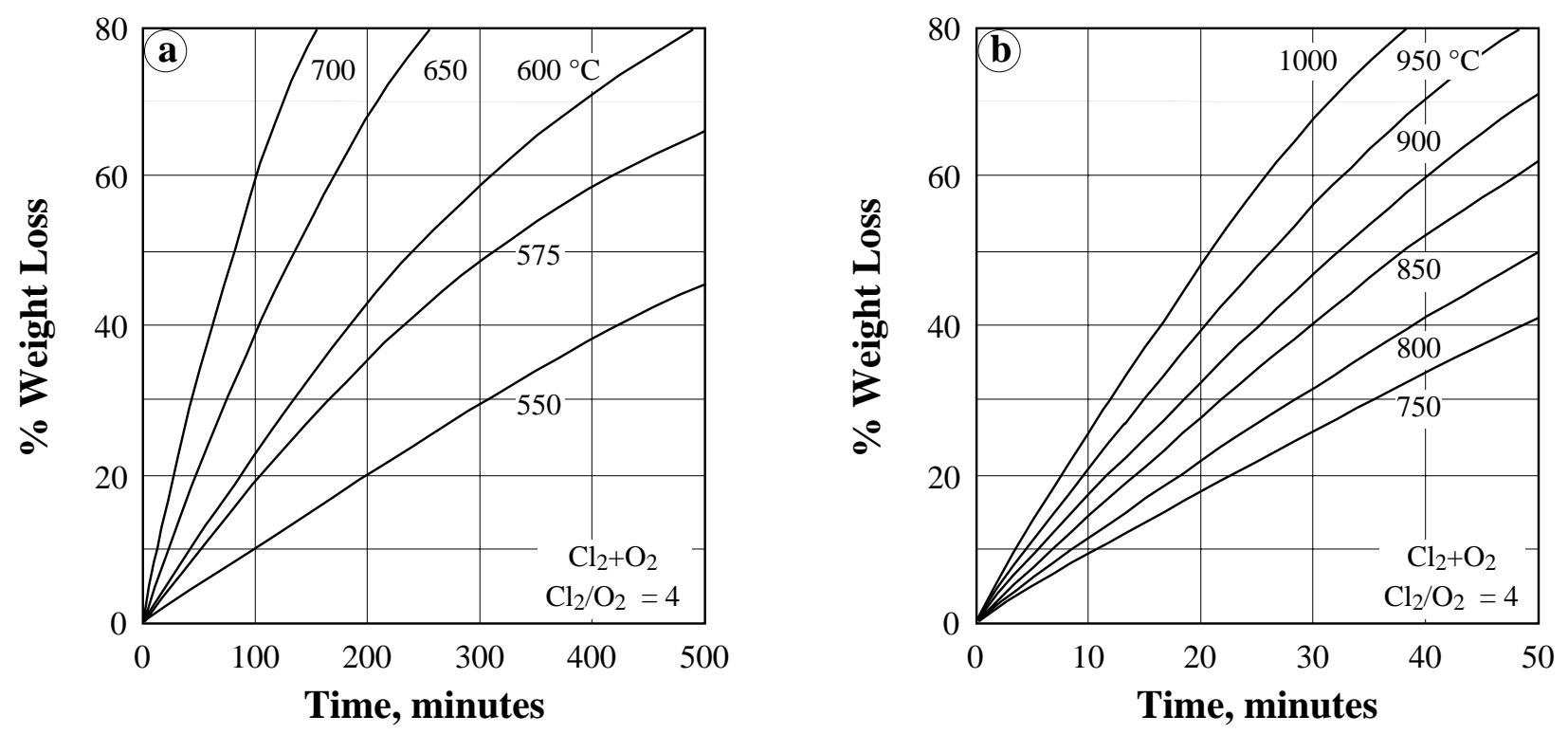

Fig. 14- Isotherms of chlorination of $\mathrm{Cr}_{2} \mathrm{O}_{3}$ with $\mathrm{Cl}_{2}+\mathrm{O}_{2}$ for $(a) \mathrm{T} \leq 700{ }^{\circ} \mathrm{C}$ and $(b) \mathrm{T} \geq 750{ }^{\circ} \mathrm{C}$.

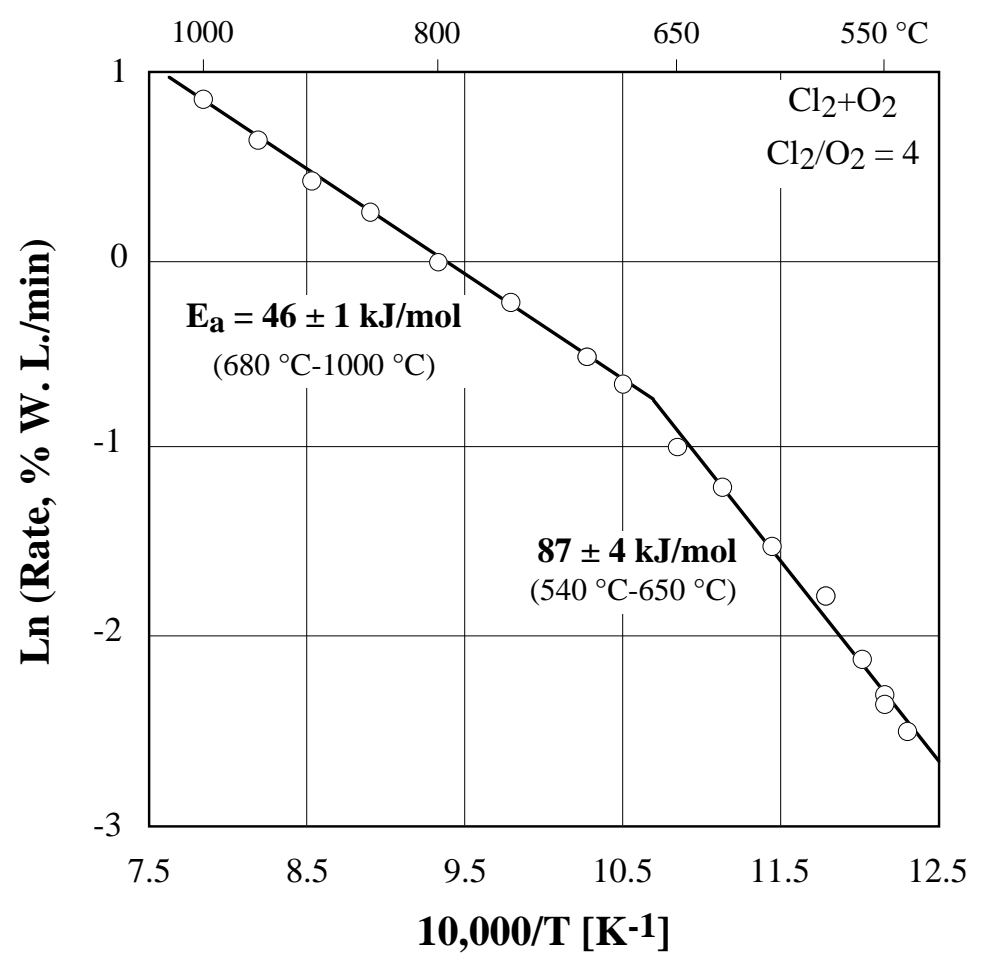

Fig. 15- Arrhenius plot of chlorination of $\mathrm{Cr}_{2} \mathrm{O}_{3}$ by $\mathrm{Cl}_{2}+\mathrm{O}_{2}$. 


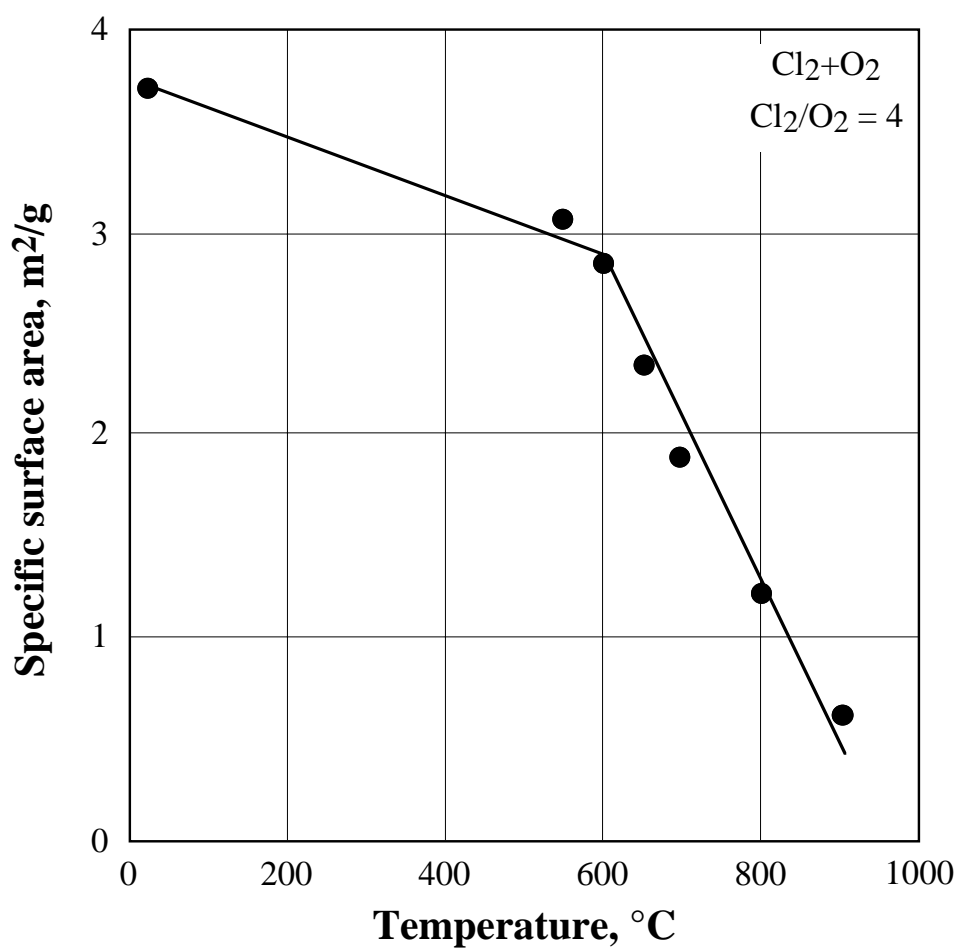

Fig. 16- Evolution of the specific surface area of partially oxychlorinated samples $(X \approx 0.27)$ of $\mathrm{Cr}_{2} \mathrm{O}_{3}$ as a function of temperature.
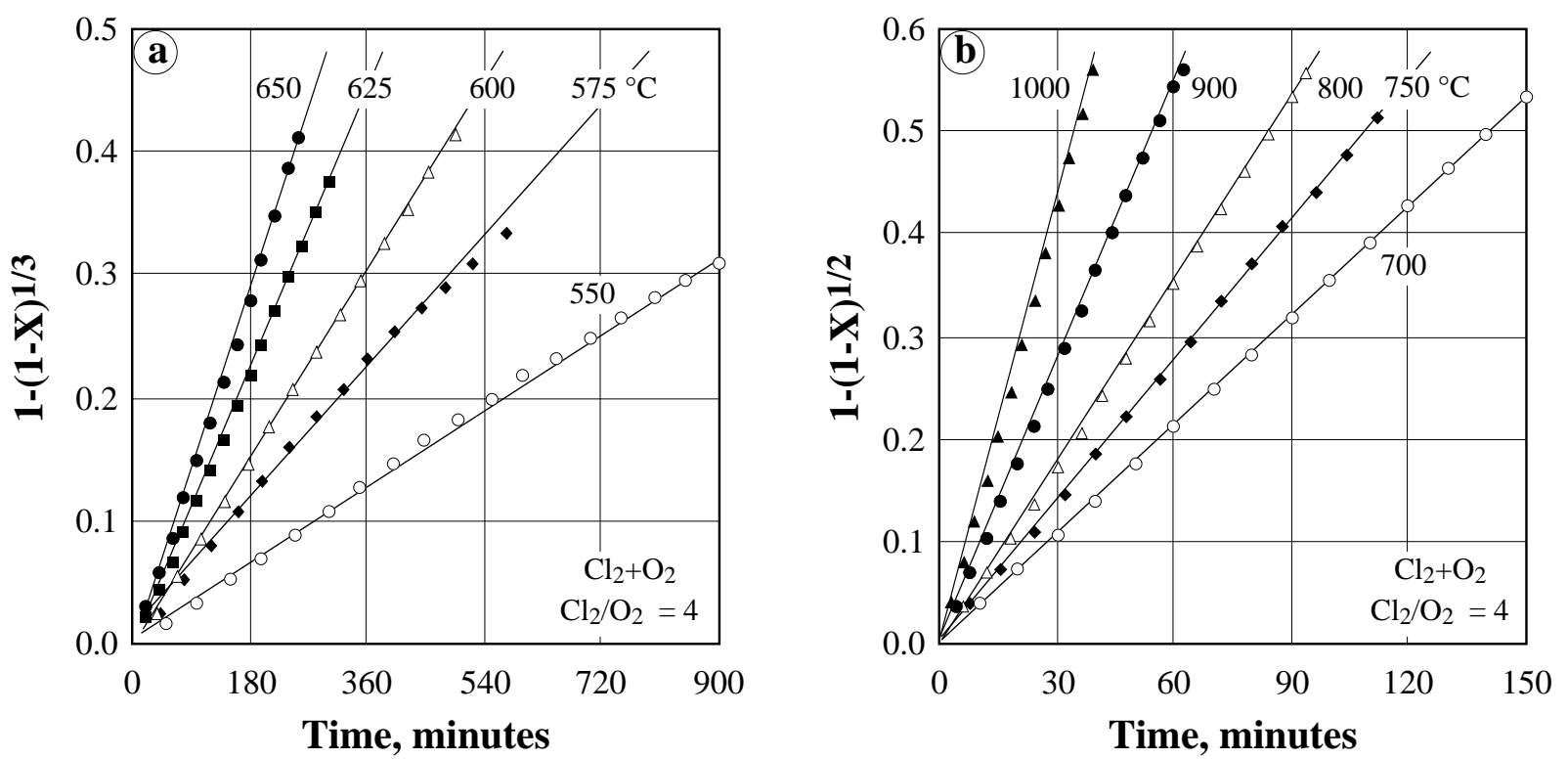

Fig. 17- Mathematical fitting of the oxychlorination data at $(a) \mathrm{T} \leq 650{ }^{\circ} \mathrm{C}$ and $(b) \mathrm{T} \geq 700{ }^{\circ} \mathrm{C}$ using Eqs 14 and 13, respectively. 

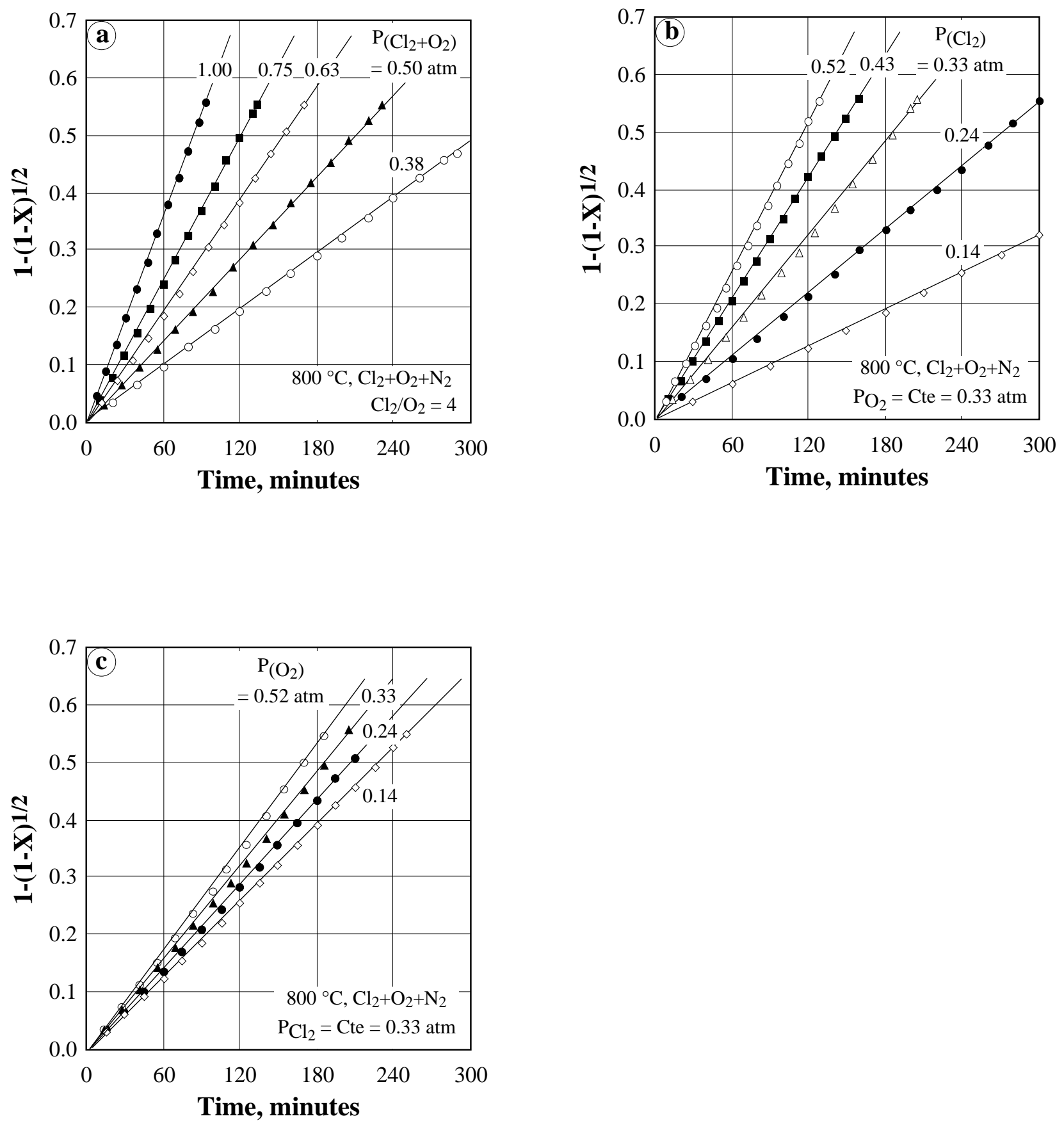

Fig. 18- Mathematical fitting of the oxychlorination data at $800{ }^{\circ} \mathrm{C}$ using Eq 13 :

(a) for different $\left(\mathrm{Cl}_{2}+\mathrm{O}_{2}\right)$ partial pressure,

(b) for different $\mathrm{Cl}_{2}$ partial pressure,

(c) for different $\mathrm{O}_{2}$ partial pressure. 


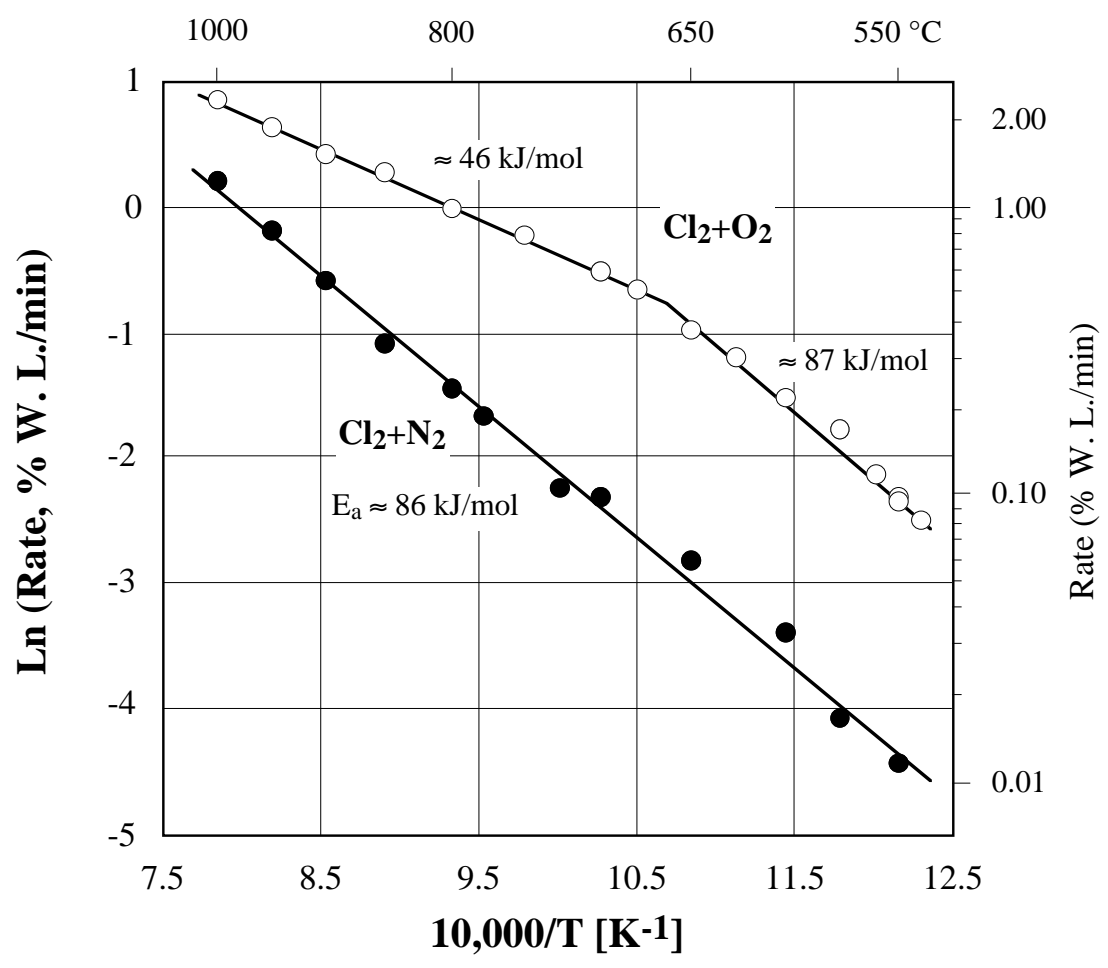

Fig. 19- Comparison of Arrhenius plots of chlorination and oxychlorination of $\mathrm{Cr}_{2} \mathrm{O}_{3}$. 